\title{
Protein targets of inflammatory serine proteases and cardiovascular disease
}

\author{
Ram Sharony ${ }^{1}$, Pey-Jen Yu², Joy Park², Aubrey C Galloway², Paolo Mignatti ${ }^{2,3}$, Giuseppe Pintucci ${ }^{2 *}$
}

\begin{abstract}
Serine proteases are a key component of the inflammatory response as they are discharged from activated leukocytes and mast cells or generated through the coagulation cascade. Their enzymatic activity plays a major role in the body's defense mechanisms but it has also an impact on vascular homeostasis and tissue remodeling. Here we focus on the biological role of serine proteases in the context of cardiovascular disease and their mechanism(s) of action in determining specific vascular and tissue phenotypes. Protease-activated receptors (PARs) mediate serine protease effects; however, these proteases also exert a number of biological activities independent of PARs as they target specific protein substrates implicated in vascular remodeling and the development of cardiovascular disease thus controlling their activities. In this review both PAR-dependent and -independent mechanisms of action of serine proteases are discussed for their relevance to vascular homeostasis and structural/functional alterations of the cardiovascular system. The elucidation of these mechanisms will lead to a better understanding of the molecular forces that control vascular and tissue homeostasis and to effective preventative and therapeutic approaches.
\end{abstract}

\section{Introduction}

Inflammation is a process that delivers defensive tools to injured tissues. Tissue injury implies changes to blood vessels and disruption of normal histological features with rapid recruitment of leukocytes; during this process inflammatory mediators coordinate the response in a manner that preserves both vascular integrity and circulation while allowing extravasation of leukocytes, i.e. their recruitment from circulation to the site of injury. Such perturbation of vascular homeostasis results in biological and biochemical reactions that mediate phenotypic changes both locally and systemically. A typical example of localized phenotypic change is the injuryinduced vascular remodeling which ultimately leads to neo-intimal hyperplasia. Systemically, inflammatory perturbation of homeostatic mechanisms affects the vascular tone, often sustaining a hypertensive phenotype.

Activated leukocytes are widely implicated in cardiovascular disease (CVD). Mononuclear cells are recruited to sites of vascular injury thus contributing to foam cells within atherosclerotic plaques [1]; macrophages infiltrate adipose tissue producing a variety of chemokines and

\footnotetext{
*Correspondence: pintug01@nyumc.org

${ }^{2}$ Department of Cardiothoracic Surgery, New York University School of

Medicine, 530 First Avenue, New York, NY 10016, USA

Full list of author information is available at the end of the article
}

cytokines, a key process to the establishment of metabolic syndrome [2]; furthermore, polymorphonuclear cells (PMN) recruited to sites of vascular injury contribute significantly to the development of neo-intimal hyperplasia as they sustain mobilization of medial smooth muscle cells that proliferate and migrate into the neo-intima [3]. Leukocyte activation occurs in all the conditions associated with an increased CVD risk: infection, hypertension, hyperlipidemia, hyperglycemia, obesity, and atherosclerosis [4]. Activated white blood cells discharge into the surrounding milieu reactive oxygen species (ROS) and a variety of proteolytic enzymes, particularly serine proteases [5]. The inflammatory serine protease response is further strengthened by activation of the kallikrein system [6], the involvement of mast cells with the release of chymase and tryptase [7], and activation of the coagulating cascade which ultimately leads to thrombin formation with locally elevated levels of thrombin activity $[8,9]$.

Sequencing of the human genome shows that more than $2 \%$ of all human genes are proteases or protease inhibitors, indicating the overall importance of proteolysis in human biology [10]. The human degradome consists of at least 561 proteases and homologs, which are distributed into 186 metallo-, 178 serine-, 21 aspartic-, 148 cysteine-, and 28 threonine- proteases [11]. A 
number of studies have emphasized that in addition to their direct proteolytic effect(s) proteases possess a variety of regulatory functions that are mediated through intracellular signaling pathways, caspase-like enzyme activity and/or regulation of specific cytokines and signaling receptors. Therefore, proteases are now considered as multifunctional, hormone-like signaling molecules that play a pivotal role in various physiological and pathological processes [12]. Protease-mediated signaling can proceed via specific protease-activated receptors (PAR) and/or PAR-independent mechanisms.

In this review we will focus on serine proteases, which have a direct effect on degradation of proteins of the extracellular matrix including collagen, elastin, and fibronectin [13]. Pro-inflammatory effects of serine-proteases will be discussed particularly in light of their relevance to CVD. We will also consider serine proteases' specific targets whose induction and/or degradation has a demonstrated impact on their biological activity and the pathogenesis of cardiovascular disease.

\section{Protease-activated receptors (PARs)}

Most serine proteases transduce their signal(s) into the cell by interacting with specific cell membrane receptors. This mechanism controls a number of relevant cellular effects of serine proteases. Protease-activated receptors (PARs) are a unique class of transmembrane $\mathrm{G}$ protein-coupled receptors (GPCRs) that play a critical role in thrombosis, inflammation, and vascular biology. Leger et al. [14] reported that all the four PARs described to date are expressed in various types of cells present in the vasculature and modulate the responses to coagulation proteases during thrombosis and inflammatory states. $\mathrm{PAR}_{1}$ and $\mathrm{PAR}_{2}$ expressed in smooth muscle cells and $\mathrm{PAR}_{1}, \mathrm{PAR}_{2}$, and $\mathrm{PAR}_{4}$ expressed in macrophages activate inflammatory and proliferative pathways in atherosclerotic lesions [15]. Rodent platelets lack $\mathrm{PAR}_{1}$ and instead use $\mathrm{PAR}_{3}$ to enhance thrombin cleavage of the lower-affinity $\mathrm{PAR}_{4}$ [14]. $\mathrm{PAR}_{2}$ is mostly a receptor for the tissue factor/factor VIIa/factor Xa complex and is also a preferred target of trypsin, but not thrombin $[16,17]$. $\mathrm{PAR}_{1}$ and $\mathrm{PAR}_{4}$ signaling show considerably different kinetics and indeed appear to have distinct functions in platelet aggregation [14]. $\mathrm{PAR}_{1}$ is a high-affinity receptor for thrombin by virtue of a hirudin-like sequence that resides in its $\mathrm{N}$-terminal extracellular domain $[18,19]$. Signal transduction via $\mathrm{PAR}_{1}$ is fast and transient, and is followed by a prolonged signaling arising from $\mathrm{PAR}_{4}$, a receptor normally more slowly activated by thrombin. For activation, $\mathrm{PAR}_{1}$ exo-domain harbors a hirudin-like sequence element that interacts with thrombin. $\mathrm{PAR}_{4}$ has an optimal cleavage sequence that provides high-affinity interactions with the active site and uses an anionic cluster for slow dissociation from the cationic thrombin. $\mathrm{PAR}_{1}$ also acts as a cofactor for thrombin activation of $\mathrm{PAR}_{4}$ which provides a mechanistic basis to understand $\mathrm{PAR}_{1} / \mathrm{PAR}_{4}$ synergy [14]. Human platelets express both $\mathrm{PAR}_{1}$ and $\mathrm{PAR}_{4}$ which give rise to a coordinated thrombin response and subsequent activation of the glycoprotein GP IIb/IIIa, a fibrinogen receptor, with formation of platelet-rich thrombi.

PARs have a unique mechanism of activation that distinguishes them from other seven transmembrane GPCRs that are activated reversibly by small hydrophilic molecules to elicit cellular responses [20]. PAR activation involves the proteolytic unmasking of the receptor's $\mathrm{N}$ - terminus to reveal a cryptic tethered ligand (TL) that binds to and activates the receptor [21]. PARs, with the exception of $\mathrm{PAR}_{3}$, are also activated by short synthetic peptide sequences derived from the sequences of the proteolytically revealed TL $[19,22]$. It is worth mentioning that proteases can also exert a negative regulation through PARs by 'disarming' the receptor by cleavage at a non-receptor activating site which results in removing the TL. Minami and collaborators [23] have described several steps following initial stimulation of PAR. Thrombin activates $\mathrm{PAR}_{1}$ by binding to a unique site in the extracellular domain of the receptor, resulting in cleavage between Arg41 and Ser42 and subsequent exposure of a new $\mathrm{N}$-terminus. The unmasked tethered ligand (SFLLRN) interacts with the extracellular loop 2 of the receptor (amino acids 248 to 268), resulting in receptor activation [24]. Once cleaved, $\mathrm{PAR}_{1}$ transmits the signal across the plasma membrane to intracellular $\mathrm{G}$ proteins. The $\mathrm{G}$ proteins are in turn associated to a number of signal intermediates that include mitogenactivated protein kinases (MAPKs), protein kinase $\mathrm{C}$ (PKC), phosphatidyl-inositol 3-kinase (PI3-K), and Akt. In normal platelets, this process culminates in morphologic changes of the cells, platelet-platelet aggregates, control of release of platelet dense granules and a rapid rise in intracellular calcium [25-27]. Thrombin signaling results in changes in downstream transcription of genes involved in cell proliferation, inflammation, leukocyte adhesion, vasomotor tone, and hemostasis. In addition, thrombin controls post-transcriptional changes such as calcium influx, cytoskeletal reorganization, and release of soluble mediators and growth factors into the extracellular matrix [23].

In reviewing the role of PARs expressed in the vascular endothelium Leger et al. [14] emphasized that their activation mediates responses involved in contractility, inflammation, proliferation, and repair complementing the functions of platelet $\mathrm{PAR}_{1}$ by localizing the thrombus to the site of vascular injury. This process involves calcium mobilization and secretion of Weibel-Palade bodies, which harbor vWF multimers and the P-selectin 
adhesion molecule [28]. Activated $\mathrm{PAR}_{1}$ thus mediates the inflammatory process in the endothelium, causes cytoskeletal rearrangements and induces cell contraction and rounding [29,30]; this mechanism destabilizes cellcell contacts with subsequent increase in vascular permeability which facilitates the passage of molecules and cells from the blood into sub-endothelial compartments while tissue factor (TF) and collagen are exposed to the vascular bed. Recent studies have indicated that PAR activation by thrombin, factor $\mathrm{Xa}$, and activated protein $\mathrm{C}$ (APC) can either promote or protect against changes in vascular permeability depending on the status of the endothelium [31,32]. $\mathrm{PAR}_{1}$ signaling can also play opposing roles in sepsis, either promoting coagulation and inflammation or reducing sepsis lethality due to APC therapy. Recombinant human activated protein $\mathrm{C}$ (hrAPC) was developed to reduce excessive coagulant and inflammatory activity during sepsis. Basic and clinical research studies have suggested that these pathways contribute to the pathogenesis of this lethal syndrome and are inhibited by rhAPC. Recent data showed that treatment with hrAPC in septic patients may improve muscle oxygenation and reperfusion and, furthermore, hrAPC treatment may increase tissue metabolism [33]. Similar to thrombin, which is a serine protease of the coagulation cascade that induces inflammatory responses and controls endothelial barrier permeability, APC, an anti-coagulant protease, also activates $\mathrm{PAR}_{1}$. Unlike thrombin, however, APC elicits anti-inflammatory responses and protects against endothelial barrier dysfunction induced by thrombin. Thus, a mechanism of protease-selective signaling by $\mathrm{PAR}_{1}$ has been suggested, called the $\mathrm{PAR}_{1}$ paradox. Russo et al. [34] have recently reported that thrombin and APC signaling were lost in $\mathrm{PAR}_{1}$ deficient endothelial cells, indicating that $\mathrm{PAR}_{1}$ is a major effector of protease signaling. They reported that thrombin caused robust Rho-A signaling but not Rac-1 activation, whereas APC stimulated a marked increase in Rac-1 activation but not Rho-A signaling, consistent with the opposing functions of these proteases on endothelial barrier integrity. Using cells lacking caveolin-1, an endothelial cell membrane protein involved in receptor-independent endocytosis, these Authors also found that APC selective signaling and endothelial barrier protective effects were mediated through compartmentalization of $\mathrm{PAR}_{1}$ in caveolae by a novel mechanism of $\mathrm{PAR}_{1}$ signal transduction regulation. Acute blockade of the APC pathway with a potent inhibitory antibody revealed that thrombin $/ \mathrm{PAR}_{1}$ signaling increases inflammation-induced vascular hyper-permeability. Conversely, APC/PAR 1 signaling and the endothelial cell protein $C$ receptor (EPCR) prevented vascular leakage, and pharmacologic or genetic blockade of this pathway sensitized mice to LPS-induced lethality.
Hence, PARs may play a role in disease states characterized by decreased barrier function, including sepsis and systemic inflammatory response syndrome, and their pharmacological modulation may therefore ameliorate serious clinical states.

Vascular smooth muscle cells (VSMC) represent sites of $\mathrm{PAR}_{1}$ over-expression in human atherosclerotic arteries, including regions of intimal thickening [35]. In vitro studies revealed that activation of $\mathrm{PAR}_{1}$ triggers mitogenic responses in VSMC and fibroblasts [36]. Moreover, a $\mathrm{PAR}_{1}$ neutralizing antibody reduced intimal hyperplasia in a catheter-induced injury model of restenosis [37]. Finally, studies using $\mathrm{PAR}_{1}$ deficient mice and small molecule $\mathrm{PAR}_{1}$ antagonists further implicated $\mathrm{PAR}_{1}$ in thrombosis and restenosis [38].

There are a number of evidences that the effect of PARs on local vessel vaso-reactivity may vary greatly depending on whether the endothelium is healthy or rather in the context of an atherosclerotic lesion. Stimulation of intact coronary arteries with thrombin or $\mathrm{PAR}_{1}$ agonist peptides elicited relaxation [39] while in atherosclerotic human coronary arteries stimulation of $\mathrm{PAR}_{1}$ failed to elicit relaxation and in some cases caused marked contraction [40].

As PARs and other GPCRs belong to the group of transmembrane receptors, they modulate $G$ protein signaling on the inside surface of the receptor [25]. Several studies utilized lipidated peptides based on the intracellular loop sequences of the GPCRs of interest like pepducins, which bind to the receptor-G protein interface on the inner leaflet of the plasma membrane. These molecules have been studied extensively in the context of $\mathrm{PAR}_{1}$ and $\mathrm{PAR}_{4}$ signaling in platelets and in animal models of thrombosis, inflammation, angiogenesis, and migration and invasion of cancer cells [14,41-43]. PAR and $\mathrm{PAR}_{2}$ mediate various vascular effects including regulation of vascular tone, proliferation and hypertrophy of smooth muscle cells and angiogenesis. Since proteases are activated under pathological conditions such as hemorrhage, tissue damage, and inflammation, PARs are suggested to play a critical role in the development of functional and structural abnormality in the vascular lesion $[44,45]$. Therefore, development of new strategies for the prevention and therapy of vascular diseases can be achieved by understanding the functional role of PARs in the vascular system.

\section{PAR-independent serine protease activity affecting the cardiovascular system}

Although many studies have explored the role of PARs in protease signaling a number of alternative mechanisms can account for protease biological activity in controlling the cardiovascular system. Here we will discuss inflammatory serine proteases as they exert their 
Table 1 Summary of protein targets of inflammatory serine proteases

\begin{tabular}{|c|c|c|c|c|}
\hline $\begin{array}{l}\text { Serine } \\
\text { protease }\end{array}$ & Targets & Function & $\begin{array}{l}\text { Role in } \\
\text { cardiovascular } \\
\text { disease }\end{array}$ & References \\
\hline Elastase & $\begin{array}{c}\text { E-cadherin, GM-CSF, IL-1, IL-2, } \\
\text { IL-6, IL8, p38 }{ }^{\mathrm{MAPK}}, \mathrm{TNF} \alpha \\
\text { VE-cadherin }\end{array}$ & $\begin{array}{l}\text { Degrades ECM components } \\
\text { Regulates inflammatory response } \\
\text { Activates pro-apoptotic signaling }\end{array}$ & $\begin{array}{c}\text { Promotes } \\
\text { atheromatous plaque } \\
\text { formation } \\
\text { Promotes vascular } \\
\text { damage } \\
\text { Promotes ischemia } \\
\text { and reperfusion injury } \\
\text { Triggers endothelial } \\
\text { cell apoptosis }\end{array}$ & {$[13,46-50,57,78,89,90,92]$} \\
\hline $\begin{array}{c}\text { Cathepsin } \\
\mathrm{G}\end{array}$ & $\begin{array}{c}\text { EGF, ENA-78, IL-8, MCP-1, MMP-2, } \\
\text { MT1-MMP, } \\
\text { PAI-1, RANTES, TGF } \beta, \text { TNF } \alpha\end{array}$ & $\begin{array}{c}\text { Degrades ECM components } \\
\text { Chemo-attractant of leukocytes } \\
\text { Regulates inflammatory response } \\
\text { Promotes apoptosis }\end{array}$ & $\begin{array}{l}\text { Initiates calcification } \\
\text { and fibrosis of aortic } \\
\text { valve } \\
\text { Promotes tissue } \\
\text { remodeling } \\
\text { Induces VSMC } \\
\text { proliferation } \\
\text { Modulates } \\
\text { coagulation }\end{array}$ & {$[58-65,67,70,78,88]$} \\
\hline PR-3 & $\begin{array}{c}\text { ENA-78, IL-8, } \\
\text { IL-18, JNK, p38 }{ }^{\text {MAPK }} \\
\text { TNF } \alpha\end{array}$ & $\begin{array}{l}\text { Promotes inflammatory response } \\
\text { Activates pro-apoptotic signaling }\end{array}$ & $\begin{array}{l}\text { Promotes vascular } \\
\text { damage } \\
\text { Triggers endothelial } \\
\text { cell apoptosis } \\
\end{array}$ & {$[78,85,89,90]$} \\
\hline Thrombin & $\begin{array}{c}\text { FGF-2, } \\
\text { HB-EGF, } \\
\text { Osteo-pontin, } \\
\text { PDGF, VEGF }\end{array}$ & $\begin{array}{c}\text { Modulates activity of vascular growth } \\
\text { factors, chemokines and extracellular } \\
\text { proteins } \\
\text { Strengthens VEGF-induced } \\
\text { proliferation } \\
\text { Induces cell migration } \\
\text { Angiogenic factor } \\
\text { Regulates haemostasis }\end{array}$ & $\begin{array}{l}\text { Promotes } \\
\text { angiogenesis and } \\
\text { vascular remodeling } \\
\text { Promotes coagulation } \\
\text { and platelet } \\
\text { aggregation }\end{array}$ & {$[14,23,31,98-101,118,122,123,173,174]$} \\
\hline Kallikreins & $\begin{array}{l}\text { high molecular weight } \\
\text { kininogen, pro-urokinase }\end{array}$ & $\begin{array}{c}\text { Modulate relaxation response } \\
\text { Contribute to inflammatory response } \\
\text { Fibrin degradation }\end{array}$ & $\begin{array}{l}\text { Impact fibrinolysis and } \\
\text { vascular tone } \\
\text { Induce relaxation of } \\
\text { contracted aortas }\end{array}$ & {$[132-136,140,141]$} \\
\hline $\begin{array}{l}\text { Tryptase } \\
\text { and } \\
\text { Chymase }\end{array}$ & $\begin{array}{c}\text { angiotensin I, fibrinogen, pro- } \\
\text { urokinase, } \\
\text { TGF } \beta\end{array}$ & $\begin{array}{c}\text { Activate pro-urokinase } \\
\text { Promote angiogenesis } \\
\text { Modulate coagulation cascade }\end{array}$ & $\begin{array}{l}\text { Affect blood pressure } \\
\text { Promote angiogenesis } \\
\text { Promote remodeling } \\
\text { of fibrotic tissue } \\
\text { Impact fibrinolysis and } \\
\text { vascular tone }\end{array}$ & {$[7,142-147]$} \\
\hline
\end{tabular}

biological activity on the cardiovascular system by targeting cytokines, growth factors, membrane receptors, and other vasoactive proteins with or without the involvement of PARs (Table 1).

\section{Neutrophil serine proteases}

Elastase is the major serine protease contained in the azurophile granules of polymorphonuclear cells (PMN, or neutrophils). When discharged upon PMN activation neutrophil elastase has a direct effect on the degradation of extracellular matrix components, including collagen, elastin and fibronectin [13]. In addition, elastase has a pro-inflammatory effect. It degrades inter-endothelial VE-cadherin and inter-epithelial E-cadherin, promoting permeability through these cell layers [46,47]. Elastase also stimulates the secretion of granulocyte-macrophage colony-stimulating factor (GM-CSF), IL-6 and IL-8 from epithelial cells $[48,49]$ and at the same time is capable of degrading the cytokines IL-1 $\beta$, IL-1, IL-8, IL-2 [50]. This effect further enhances leukocyte migration and propagates inflammation.

The net effect of proteolytic activity depends on the balance between a pro-inflammatory and an anti-inflammatory state. In various diseases an imbalance in the ratio of proteases and their physiological inhibitors has a role in the progression of the pathologic process. For example, inherited deficiency of 1-proteinase inhibitor (1-PI), the principal extracellular inhibitor of neutrophil elastase, increases the risk of severe early-onset emphysema [51]. Conversely, Ortiz-Muñoz et al. [52] have recently shown the presence of ${ }_{1}$-antitrypsin in highdensity lipoprotein (HDL) that possesses a potent antielastase activity. The same Authors also reported that 
HDL-associated ${ }_{1}$-antitrypsin was able to inhibit extracellular matrix degradation, cell detachment, and apoptosis induced by neutrophil elastase in human VSMCs and in mammary artery cultured ex vivo [52].

Thrombus formation at the surface of an atherosclerotic plaque in coronary or carotid arteries may cause acute occlusion and subsequent complications such as myocardial infarction or stroke leading to serious clinical conditions. Such pathological events caused by rupture of a thin-capped fibro-atheroma containing a lipidrich necrotic core lead to the exposure of plaque-associated tissue factor to circulating coagulation factors, platelet activation, and subsequently to the formation of an occlusive thrombus $[53,54]$. The atherosclerotic plaque may be stable for a long time or rather prone ("vulnerable") to disruption. A huge scientific effort is justifiably under way in order to characterize the vulnerability of the atherosclerotic plaque.

Extracellular protease levels increase with the major coronary risk factors. Smoking and Type 1 diabetes increase plasma elastase levels [55,56]. Dollery et al. [57] showed in human tissue that fibrous and atheromatous plaques but not normal arteries contained significant amounts of neutrophil elastase. Moreover, elastase abounded in the macrophage-rich shoulders of atheromatous plaques with histological features of vulnerability. These Authors also showed by in situ hybridization that elastase was highly expressed in macrophage-rich areas, indicating local production of this enzyme.

Cathepsin G is another serine protease of PMN azurophile granules that hydrolyses several types of proteins. Cathepsin $\mathrm{G}$ exerts potent pro-inflammatory properties [58]. It plays a role in the degradation of extracellular matrix components and cytokines and also as a chemoattractant for leukocytes, including $\mathrm{T}$ cells. Cathepsin G has a potent elastolytic activity and thus plays a key role in tissue remodeling $[59,60]$. Cathepsin $G$ cleaves and activates $G$ protein-coupled receptors (GPCRs) as a mechanism to modulate coagulation and tissue remodeling at sites of injury and inflammation (see above). Cathepsin $G$ also induces activation of the matrix metallo-proteinases MMP-2 and MT1-MMP. In fact, myocytes treated with an MMP-2 inhibitor display reduced ERK-1/2 phosphorylation and attenuated apoptosis induced by cathepsin G. In addition, inhibition of MT1-MMP by either TIMP-2 or neutralizing MT1MMP antibodies blocks cathepsin G-induced MMP-2 activation and ERK-1/2 phosphorylation [61]. A decrease in apoptosis has also been observed in a model of cathepsin $\mathrm{G}^{-/-}$mice [62]. Cathepsin G-mediated cell detachment and apoptosis have also been demonstrated in cultured cardiomyocytes [63]. Our group and others have shown the role of MT1-MMP in cathepsin Ginduced MMP-2 cleavage and epidermal growth factor receptor (EGFR) trans-activation $[61,64]$. Cathepsin Ginduced cardiomyocyte apoptosis involves an increase in EGFR-dependent activation of protein tyrosine phosphatase SHP2 (Src homology domain 2-containing tyrosine phosphatase 2) which promotes focal adhesion kinase dephosphorylation and subsequent cardiomyocyte anoikis, the apoptotic response of cells to the absence of cell-matrix interactions [64].

The chemokine RANTES (Regulated upon Activation, Normal T-cell Expressed and Secreted) is strongly induced by viral and bacterial infections and plays a role in allergic diseases, asthma exacerbation, interstitial pneumonia, allograft rejection and in some types of cancers. Recently, RANTES has been shown to induce VSMC proliferation in an animal model of graft arterial disease [65]. Interestingly, the RANTES specific allele is associated with the presence and severity of coronary artery disease [66]. Cathepsin G mediates the regulation of RANTES signaling pathway. In fact, Lim et al. [67] showed that cathepsin $G$ promotes post-translational processing of RANTES into a variant lacking N-terminal residues, called 4-68 RANTES, which exhibits less efficient binding to the chemokine receptor CCR5 and lower chemotactic activity [68]. In this study, it was also shown that the cathepsin $G$ inhibitor Eglin $C$ abrogated cell-mediated production of 4-68 RANTES. Furthermore, neutralizing cathepsin $\mathrm{G}$ antibodies also abrogated RANTES digestion in neutrophil cultures. These findings demonstrate that cathepsin $\mathrm{G}$ proteolytic activity operates a tight control of RANTES.

Cathepsin G enzymatic activity can lead to generation of angiotensin II which in turn induces the expression of monocyte chemoattractant protein-1 (MCP-1) [69], and also triggers an angiotensin II-dependent profibrotic response mediated by transforming growth factor-beta 1 (TGF- $\beta 1$ ). In addition to its pro-fibrotic effect, cathepsin G-mediated TGF- $\beta 1$ formation also initiates calcification of the aortic valve [70]. Hence, cathepsin G-mediated TGF- $\beta 1$ formation may be associated with both fibrosis and calcification of the aortic valve, two important mechanisms of valvular disease. It has also been reported that cathepsin $G$ expression is significantly increased in human stenotic aortic valve and that this is associated with the formation of atheroma of the carotid artery [71].

Reperfusion of ischemic tissues induces an inflammatory response $[72,73]$. This process is associated with cytokine and chemokine production and expression of adhesion molecules, neutrophil infiltration and subsequent tissue damage $[74,75]$. Studies using animal models have shown that neutrophil depletion before reperfusion or blockade of neutrophil infiltration into the ischemic tissue results in attenuating the injury associated with ischemia-reperfusion $[76,77]$. Cathepsin 
$\mathrm{G}^{-/-}$mice have normal development of neutrophils but an abnormal wound healing response. These mice also present a reduced tissue injury in a model of renal ischemia-reperfusion; cathepsin $G$ thus appears to be a critical factor for sustaining neutrophil-mediated acute tissue pathology and subsequent fibrosis [62].

Tumor necrosis factor-alpha (TNF- $\alpha$ ) is one of the major cytokines involved in the inflammatory response. Proteolytic cleavage of the membrane-bound pro-form of TNF- $\alpha$ is a requirement for its biological activity. Elastase and cathepsin $\mathrm{G}$ are both involved in the shedding of membrane-bound TNF- $\alpha$. Elastase and Proteinase-3 (PR-3), another protease contained in the azurophile granules, are both able to process TNF- $\alpha$ in vitro into its soluble, active form [78] whereas serine protease inhibitors suppress the secretion of TNF- $\alpha$ from activated macrophages [79,80].

The ADAM (A Disintegrin And Metallo-proteinase) family of peptidases are involved in a process called 'shedding', i.e the cleavage and release of a soluble ectodomain from membrane-bound pro-proteins. ADAM metallopeptidase with thrombospondin type 1 motif, 17 (ADAMTS17) is the main physiological TNF- $\alpha$ processing enzyme. However, studies conducted with cultured fibroblasts isolated from ADAMTS17 $7^{-/-}$animals have shown that both elastase and cathepsin $\mathrm{G}$ release soluble TNF- $\alpha$ (diminishing the levels of the membrane-bound form and increasing the levels of biologically active, soluble TNF- $\alpha$ ). In contrast to cathepsin G, elastase is also able to further degrade, and thus inactivate, soluble TNF- $\alpha$, although at higher concentrations $[81,82]$. Thus, these proteases modulate the levels of soluble TNF- $\alpha$ contributing to control its pro-inflammatory activity in the tissue.

The cytokine IL-18 plays a role in inflammatory states like sepsis, arthritis and inflammatory bowel disease $[83,84]$. Its inactive precursor pro-IL-18 is generally cleaved by caspase- 1 to its active form. In vitro, PR-3 activates IL-18 independently of caspase- 1 activity. This has been elegantly confirmed using a caspase-1-deficient mouse model [85].

In addition to the cytokines mentioned above neutrophil serine proteases can cleave a number of ligandbinding cytokine receptor ectodomains. This cleavage appears to modulate the cellular response by inactivating the receptor or prolonging the cytokine half-life $[86,87]$ with subsequent down-regulation of the inflammatory response. It should be noticed that proteolytic cleavage of cytokines like IL- 8 and ENA-78 by PR-3 and cathepsin $G$ leads to a more active form of the chemokines. Therefore, neutrophil serine proteases, by activating specific receptors and releasing or inactivating a number of cytokines, modulate the dynamic state of cytokines at the site of inflammation.
The potential effects of cathepsin $G$ in cardiovascular disease may also derive from its control of the fibrinolytic system. While investigating cathepsin $\mathrm{G}$ biological effects on human endothelial cells we discovered that cathepsin $\mathrm{G}$ induced suppression of tissue-type plasminogen activator (tPA) activity and that this effect was mediated by release of its physiological inhibitor plasminogen activator inhibitor 1 (PAI-1) from the endothelial extracellular matrix [88]. Interestingly, in the same study we discovered that cathepsin $G$ was able to release PAI1 from platelets, thus strengthening its potential role as a thrombogenic factor.

The complexity of the impact of leukocyte-derived proteases processing of specific substrates on intracellular signaling pathways has several repercussions on the vascular cell phenotype. Yang et al. [89] found that release of PR-3 and elastase by activated neutrophils during acute inflammation may result in vascular damage by triggering endothelial cell apoptosis. This group also reported that the release of neutrophil and monocyte proteases, such as PR-3 and elastase, can facilitate the passage of these white blood cells through the endothelial cell layer with the concomitant activation of pro-apoptotic signaling pathways such as the stress-activated mitogen-activated protein kinases (MAPKs). Accordingly, inhibition of the MAPK JNK blocked PR-3-induced apoptosis, and also inhibition of p38 ${ }^{\text {MAPK }}$ blocked PR3- and elastase-induced apoptosis, indicating that these pathways are required for activation of apoptosis by these proteases [90].

The inhibition of neutrophil elastase ameliorates ischemia and reperfusion injury as shown in a mouse liver model. Treatment with an elastase inhibitor decreased local neutrophil infiltration and diminished apoptosis as determined by terminal deoxy-nucleotidyl transferase-mediated dUTP nick-end labeling (TUNEL) staining and caspase- 3 cleavage. Thus, targeting neutrophil elastase represents a useful approach for preventing ischemia and reperfusion injury [91] which suggests potential applications for the therapy of cardiovascular diseases. In addition, an in vitro study using isolated PMN from venous blood of healthy volunteers showed that also $\mathrm{C}$-reactive protein (CRP) degradation products generated by NE promoted neutrophil apoptosis and cell death. Therefore, cleavage of CRP by neutrophil elastase may have a role in modulation of inflammatory injury (see below for more data on CRP) [92].

However, it should be pointed out that studies on different cell types, i.e. epithelial cells, have shown that there is a dual cellular response to elastase in acute inflammation that includes the activation of both proapoptotic and pro-survival pathways, the balance of which ultimately determines the cell's fate [93]. 


\section{Thrombin and growth factor signaling}

The cardiovascular system's development and maintenance are tightly controlled by the concerted activities of a variety of vascular growth factors. These include vascular endothelial growth factor (VEGF), fibroblast growth factors (FGFs), heparin-binding epidermal growth factor (HB-EGF) and platelet-derived growth factors (PDGFs) which all act via specific cell membrane receptors known as receptor tyrosine kinases (RTKs); their activation triggers multiple intracellular signaling pathways [94]. The impact of these growth factors on angiogenesis and vascular remodeling has been widely documented and several approaches aimed to interfering with these processes by selectively inhibiting the growth factor activity directly or indirectly have shown a variable degree of success [95-97]. Interestingly, thrombin, a serine protease activated upon tissue injury and inflammation, modulates the activity of most vascular growth factors, which in part explains its angiogenic properties. In fact, thrombin not only releases VEGF from tumor cells but also strengthens VEGF-induced proliferation of vascular endothelial cells via upregulation of VEGF receptors expression [98]. The thrombin-induced shedding of HB-EG from the cell membrane controls VSMC proliferation by transactivating the EGF receptor [99]; interestingly, the intracellular response triggered by thrombin via this mechanism induces a biphasic activation of the ERK-1/2 pathway which seems to be mediated by MMPs [100]. Thrombin also modulates the expression of PDGF, a growth factor implicated in the stabilization of angiogenic vessels through pericyte maintenance as well as in the development and progression of intimal hyperplasia, a process synergistically supported in concert with basic FGF (FGF-2) [101,102]. Thrombin strengthens the biological activity of FGF-2 which mediates its effects, particularly on VSMC [103-109]. Our group has characterized several effects of FGF-2 on vascular cells, including its critical role in inducing endothelial cell migration via activation of the MAPKs ERK-1/2 [110,111]. As our recent findings have unraveled a novel mode of interaction between thrombin and FGF-2 (see below) we will discuss these two molecules in further detail.

FGF-2 is the prototypic member of a family of small proteins with pleiotropic effects [112]. The $f g f-2$ human gene is expressed in different molecular weight forms generated by alternative translation from a single mRNA transcript. Translation of the $18 \mathrm{kDa}$ form or low molecular weight (LMW) FGF-2 is initiated from a classical AUG codon, whereas the 22, 22.5 and $24 \mathrm{kDa}$ forms, collectively known as high molecular weight (HMW) FGF-2, are translated from alternative CUG codons upstream of the AUG [113,114]. The HMW forms of FGF-2 are therefore colinear extensions of 18 kDa FGF-
$2[115,116]$. Within the cell HMW FGF-2 is predominately localized to nuclei and nucleoli, whereas LMW FGF-2 is mostly cytoplasmic; importantly, both forms are also detected into the extracellular environment although the mechanism of their release remains poorly understood. Selective expression of HMW FGF-2 is induced by stress conditions such as heat shock and oxidative stress, and by specific cytokines and growth factors (reviewed in Yu et al. [116]). The different FGF-2 forms have been implicated in various pathological processes, including vascular remodeling and arterial restenosis, neuronal regeneration after injury and tumor growth [116,117].

The serine protease thrombin is a key regulator of vascular integrity and homeostasis; it is a key enzyme of the coagulation cascade, angiogenic factor, inflammatory mediator, platelet agonist and regulator of vascular cell functions [118]. Generation of thrombin through activation of the tissue factor-dependent coagulation cascade is also well described in malignancy [119]. Accordingly, thrombin has been shown to promote tumor growth and metastasis, an effect in part attributed to its angiogenic activity $[120,121]$ and its induction of chemokines, growth factors and extracellular proteins [122,123]. Most of thrombin effects are mediated by activation of specific protease-activated receptors (PARs) and their downstream intracellular signaling [124] (see above).

Thrombin effects on vascular cells have been demonstrated to depend on FGF-2; FGF-2 is also released by thrombin from the heparan sulfates that act as molecular storage for its bioavailability in the extracellular matrix $[103,106,107,109,125]$. While investigating the vascular response of a vein utilized as bypass graft in the arterial circulation (vein graft arterialization), we observed a dramatic and rapid increase in vein graftassociated thrombin activity [9]. Because this finding was paralleled by an apparent increase in LMW FGF-2 and disappearance of HMW FGF-2 in the vein graft (Fig. 1), we investigated the effect of thrombin on FGF-2 expression in various vascular cell cultures. Adding thrombin to the culture medium resulted in loss of cellassociated HMW FGF-2 and concomitant accumulation of LMW FGF-2. The rapid kinetics of this effect (5 min) suggested that it was not the result of a translational control by thrombin. In fact, using FGF- $2^{-/-}$mouse endothelial cells engineered to express solely the human HMW FGF-2 we demonstrated that thrombin cleaves HMW FGF-2 into an $18 \mathrm{kDa}$-like form of FGF-2 (ELF2). Importantly, we showed that cleavage of HMW FGF2 into ELF- 2 mediates thrombin mitogenic and promigratory effects on endothelial cells independent of PAR activation [126] (Fig. 2). Thrombin cleavage of HMW FGF-2 thus represents a rapid mechanism of post-translational control of FGF-2 activity. Therefore, 


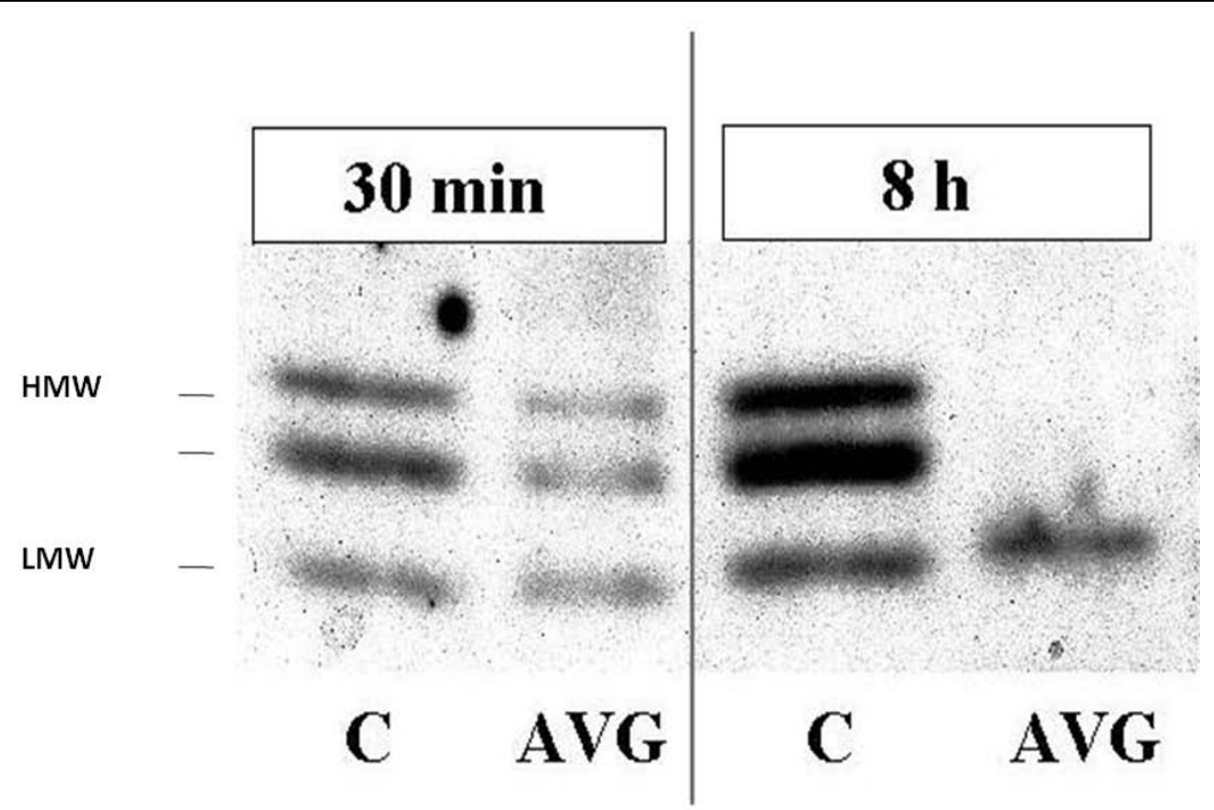

Figure 1 Western blotting analysis of FGF-2 expression in canine arterialized vein grafts (AVG) or in control femoral veins (C) harvested at the indicated times after grafting showed disappearance of HMW FGF-2 at $8 \mathrm{~h}$ and the presence of a band in the 18 kDa range.

one must conclude that thrombin induces FGF-2 activity by both translation-dependent and -independent mechanisms. Both LMW and HMW FGF-2 are massively exported from the cell upon cell death, injury or sub-lethal damage (reviewed in Yu et al. [116]). Accordingly, release of all forms of FGF-2 occurs significantly in injured endothelial cells [126]. In vivo vascular injury is accompanied by localized endothelial and smooth muscle cell damage as well as thrombin generation. These conditions are therefore ideal for thrombinHMW FGF-2 interactions in the extracellular environment.

\section{The kallikrein-related peptidases}

Kallikrein-related peptidases constitute a family of 15 (chymo)-trypsin-like proteases (KLK 1-15) that are secreted as inactive zymogens and can exhibit either trypsin- or chymotrypsin-like activity upon activation [127-129]. Kallikreins are abundantly expressed in many tissues as well as in circulation and are upregulated in disease. Increased levels of human kallikreins have been detected in ovarian and breast cancer patients [130,131] as well as at sites of inflammation [132,133]. Human kallikrein 14 (KLK 14) is the main physiological regulator of $\mathrm{PAR}_{2}$ in many settings, in addition to other serine proteases like trypsin, factor VIIa/Xa, and tryptase. Oikonomopoulou et al. [134,135] comprehensively described the role of tissue kallikreins on PARs. Based on the fact that activation of either $\mathrm{PAR}_{1}$ or $\mathrm{PAR}_{2}$, but not $\mathrm{PAR}_{4}$, induces an endothelium-dependent nitric oxide-mediated aorta relaxation [136,137] an aorta ring relaxation assay using rat or mouse vascular tissue was performed to determine whether human kallikreins could activate PARs in intact tissues. These Authors found that human KLK 5, 6, and 14 caused relaxation of rat aorta that had been pre-constricted with phenylephrine. Human KLK 14 ability to induce relaxation of precontracted aortas was further investigated using wildtype vs $\mathrm{PAR}_{2}$-null mice. In endothelium-intact murine aorta preparations human KLK 14 caused a relaxation response that was comparable to that of acetylcholine. Conversely, KLK 14 failed to cause relaxation in preconstricted tissues obtained from $\mathrm{PAR}_{2}$-null mice in which the relaxation response could still be observed in the presence of $\mathrm{PAR}_{1}$ activators (TFLLR-NH $\mathrm{N}_{2}$ or thrombin). Thus, signaling via human, rat, and murine PARs can be regulated by kallikreins. Interestingly, kallikreins, and specifically human KLK 14 , contribute to the inflammatory response [137-139].

As in the case of other serine proteases kallikreins can cleave a number of protein targets of interest for the cardiovascular system. One major example of such a mechanism is certainly the cleavage of high molecular weight kininogen operated by both plasma and tissue kallikreins off the platelet surface [140]. As the cleavage of membrane-bound high molecular weight kininogen by kallikrein releases the potent vasodilator bradykinin this mechanism has an obvious impact on vascular tone. 


\section{Thrombin Cleavage Site}

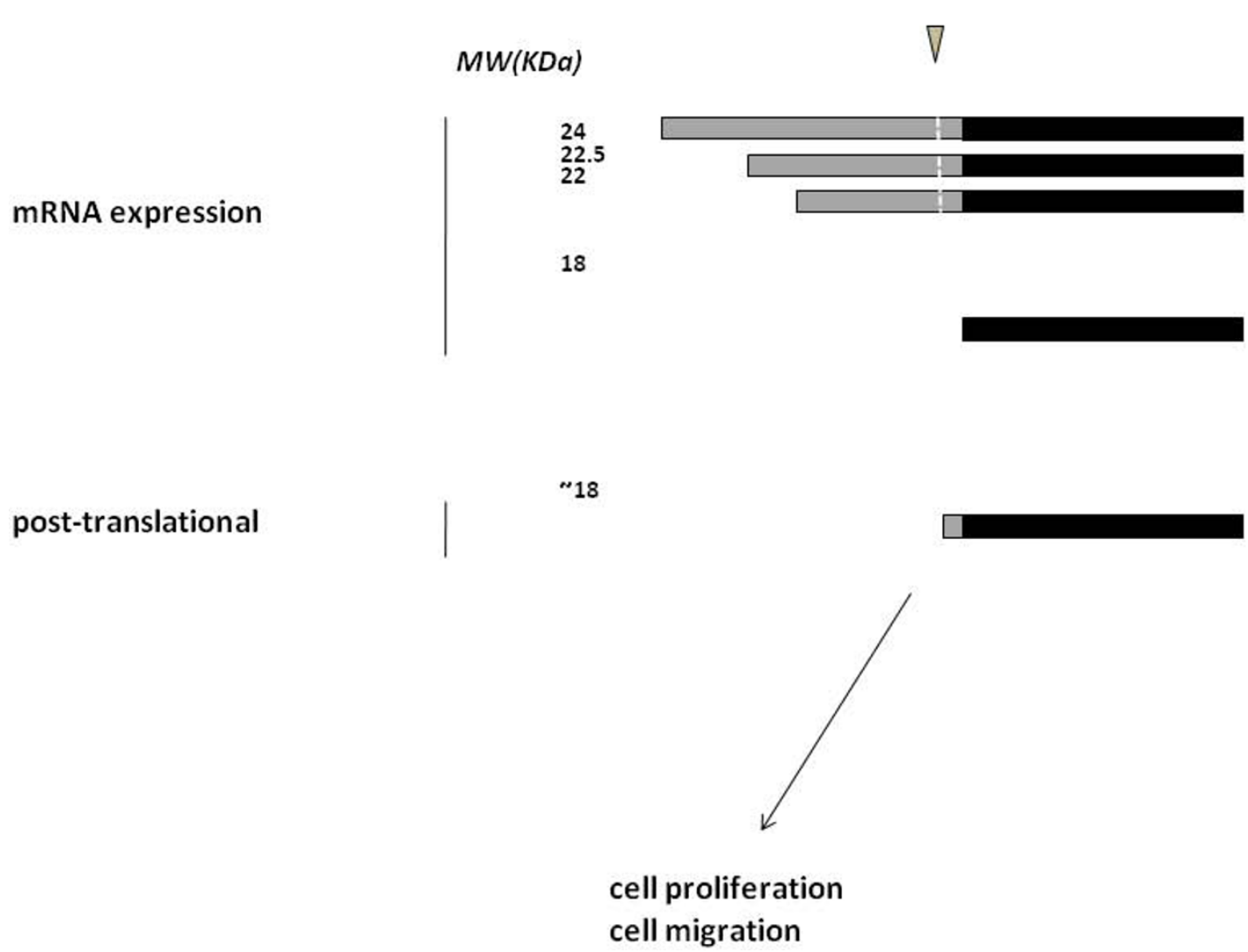

Figure 2 Schematic of the different human FGF-2 forms: high molecular weight (HMW, 24, 22.5, 22 kDA) or low molecular weight (LMW, $18 \mathrm{kDa}$ ) expressed upon alternative translation from a unique mRNA. The HMW forms (black plus grey bars) are colinear extensions of LMW FGF-2 (black bar only), and are inactive or inhibitory on vascular cell migration. Upon tissue injury and cellular damage, thrombin cleaves all HMW FGF-2 forms exported in the extracellular environment in at least three different bonds (indicated as a unique white dotted line) upstream of the initiating methionine of 18 kDa FGF-2 thus generating an eighteen kDa-like FGF-2 form (ELF-2) that induces vascular cell proliferation and migration.

Another interesting target of plasma kallikrein is prourokinase. Ichinose et al. [141] reported that the zymogen of this plasminogen activator can be converted by plasma kallikrein into a disulfide bond-linked two-chain form that degrades fibrin, its physiologic substrate; interestingly, these same Authors showed that thrombin converted pro-urokinase into a two-chain form that was not activatable by kallikrein or other serine proteases.

\section{Mast cell serine proteases}

Mast cells are mostly known for their role in allergic reactions during which vasoactive substances like histamine and cytokines as well as proteases are massively released [142]. Mast cells also play a role in the clearance of foreign bodies, including bacteria. Although cathepsin $\mathrm{G}$ can be expressed by mast cells, tryptase and chymase are the major serine proteases stored in their granules [7].
While mast cell-derived serine proteases have been shown to activate $\mathrm{PAR}_{2}$ [143] their proteolytic activity has been also shown to target specific proteins widely implicated in cardiovascular physiology and pathology. Tryptase has been shown to convert pro-urokinase into its active form [144], and chymase promotes the release of TGF- $\beta$, a pro-fibrotic growth factor and potent angiogenesis inducer, from the endothelial extracellular matrix [145]. Mast cell serine proteases have also a potential impact on vascular tone and blood coagulation. In fact, chymase has been shown to cause the in vitro conversion of angiotensin I into angiotensin II, a protein implicated in vasoconstriction and post-infarction remodeling of the heart [146]. Conversely, tryptase may impact blood coagulation by depleting fibrinogen via its proteolytic degradation [147]. 


\section{Other protein targets of serine proteases that affect the cardiovascular system}

Besides thrombin proteolysis of HMW FGF-2 (see above), studies from the early 70's had revealed that the hormone-like action of trypsin, another serine protease, is due to its effect on the insulin receptor $[148,149]$ which generates a truncated insulin alpha-subunit receptor with an intrinsic signaling activity [150]. Lafleur et al. [151] have also reported a mechanism of thrombin signaling in human endothelial cells which does not appear to involve $\mathrm{PAR}_{1}, \mathrm{PAR}_{2}$, or $\mathrm{PAR}_{4}$. These Authors demonstrated that thrombin efficiently cleaves the 64 $\mathrm{kDa}$ form of membrane-type 1 matrix metalloproteinase (MT1-MMP) in the presence of cells. Thrombin also rapidly increased cellular MT1-MMP expression and activity.

In the following paragraphs we will discuss two proteins whose implication in cardiovascular disease has been clearly established but for which the impact of their interaction with inflammatory cells and proteases on their activity in the cardiovascular system remains to be elucidated.

\section{C-reactive protein (CRP)}

$\mathrm{CRP}$, an acute phase reactant, has been recognized in recent years as an important cardiovascular risk factor and independent predictor of cardiovascular events $[1,152]$. CRP is considered a protein actively involved in atherogenesis, probably via the amplification of the vascular inflammatory response. CRP modulates neutrophil function $[153,154]$ and up-regulates TNF- $\alpha$, IL-6, IL-1 $\beta$ [155], MCP-1 [156], and tissue factor production by monocytes $[157,158]$ as well as low density lipoprotein (LDL)-uptake [159], probably contributing to foam cell formation in atherosclerotic plaques. Using a model of vein grafting into arterial circulation our group reported that CRP levels increased peaking 24 hours after surgery in serum as well as within the vein graft [160]. In situ hybridization and Northern blotting analysis, however, showed no CRP mRNA in either the arterialized vein graft (AVG) or control veins whereas a strong positive hybridization signal was detected in the liver. Early increases in AVG-associated CRP levels after arterialization are nonetheless indicative of inflammatory processes. Whether or not neutrophil release of serine proteases plays an active role in localizing circulating CRP to the vein graft remains to be determined.

It has been suggested that CRP may act as an atherothrombotic agent as it inhibits endothelial NO synthase [161] and prostacycline [162], induces expression of plasminogen activator inhibitor-1 [163], and promotes tissue factor activity in monocytes [157]. Accordingly, a recent study reported increased thrombosis after arterial injury in transgenic mice over-expressing human CRP [164].

\section{Osteopontin}

Osteopontin is an aspartic acid-rich, N-linked glycosylated secreted phosphoprotein also known as extracellular matrix cell adhesion protein. Osteopontin plays a pivotal role in cell adhesion, chemotaxis, prevention of apoptosis, invasion, and migration of various mesenchymal, epithelial, and inflammatory cells. Osteopontin is over-expressed in renal and cardiovascular cells during tissue remodeling and in inflammatory cells associated to different clinical conditions [165]. Scatena et al. [166] described osteopontin as a multifunctional molecule highly expressed in chronic inflammatory and autoimmune diseases, and thus believed to exacerbate inflammation linked to atherosclerosis [167]. Specifically, plasma osteopontin levels correlate with the presence and extent of coronary artery disease [168] and high levels of the protein have been found in patients with restenosis after percutaneous coronary intervention [169]. Furthermore, Golledge et al. [170] have shown that serum and tissue concentrations of osteopontin are associated with abdominal aortic aneurysm. These observations suggest that osteopontin may play a role in plaque formation and vascular disease progression. Several protease cleavage sites have been identified in the osteopontin molecule that may be important in regulating its activity [171]. Osteopontin was characterized as a substrate for several MMPs [172] but it also contains a domain that requires cleavage by the serine protease thrombin to be functional [173]. A functional serinevaline-valine-tyrosine-glutamate-leucine-arginine (SVVYGLR) domain has a cryptic structure in intact osteopontin and its cleavage by thrombin or matrix metallo-proteases is required in order to be functional [173]. Osteopontin structure/function studies mapped its activities to the SVVYGLR heptapeptide motif in the thrombin-liberated N-terminal domain (SLAYGLR in mouse osteopontin). In vitro studies showed that the SVVYGLR cryptic domain exposed after thrombin cleavage is able to induce adhesion and migration [174], which highlights its importance in the inflammatory process. Osteopontin levels were found significantly elevated in rheumatoid arthritis patients and appeared to correlate with the serum levels of inflammation markers [175]. An in vivo study in a mouse model of rheumatoid arthritis using a neutralizing antibody directed specifically to the SLAYGLR domain (within the osteopontin $\mathrm{N}$-terminal domain in rodents) showed that adding the synthetic heptapeptide SVVYGLR sequence greatly reduced proliferation of normal synovial cells leading to bone erosion and infiltration of inflammatory cells. The SVVYGLR peptide has also been shown to induce angiogenesis both in vitro and in vivo [176]. Giachelli et al. [177] elucidated the role of osteopontin in inflammation and reported that neutralizing antibodies to 
osteopontin blocked macrophage infiltration. Later, this group showed that neutralizing osteopontin reduced neointima formation [165] and Lai et al. [178] demonstrated in a mouse model that the osteopontin peptide SVVYGLR activates vascular pro-MMP9 and superoxide signaling. These data demonstrate the potential role of the osteopontin SVVYGLR sequence in signaling, and the importance of the regulatory mechanisms that control inflammatory diseases as well as the potential benefit in selective inhibition of osteopontin SVVYGLR signaling as a strategy to reduce inflammatory vascular remodeling [179].

The potential role of osteopontin over-expression or deficiency in atherosclerotic lesion formation has also been explored. Osteopontin is highly expressed in atherosclerotic lesions, especially in association with macrophages and foam cells $[167,180,181]$. On the other hand, Matsui et al. [182] generated osteopontin-null mice, crossed them with apolipoprotein (apo) E-deficient mice and found that female mice with osteopontin ${ }^{+/-} / \mathrm{apoE}^{-/-}$ and osteopontin ${ }^{-/-} /$apoE $^{-/-}$genotype had significantly smaller atherosclerotic and inflammatory lesions as compared to osteopontin ${ }^{+/+} / \mathrm{apoE}^{-/-}$mice. They also found that the vascular areas with deposition of minerals in 60-week-old male osteopon $\mathrm{tin}^{-1-} / \mathrm{apoE}^{-1-}$ mice were significantly increased as compared to those observed in osteopontin ${ }^{+/+} / \mathrm{apoE}^{-/-}$mice. This report was consistent with findings that mice deficient in both matrix Gla protein, a vitamin K-dependent calciumbinding protein that plays a role in calcification balance, and osteopontin had increased calcification in their arteries compared to mice that were wild-type for osteopontin and homozygous for matrix Gla protein deficiency, suggesting an inhibitory effect of osteopontin on vascular calcification [183]. However, osteopontin circulating levels correlate with both mitral valve disease secondary to rheumatic fever [184] and the presence and calcification levels of stenotic aortic valves [185]. These data further highlight the role of osteopontin in inflammation, but also suggest that in spite of relatively high concentrations in circulation, osteopontin biological activity might be controlled by its post-translational modifications. Proteolysis of osteopontin could therefore play a key role in controlling the biological role of this multifunctional protein in the context of heart valve disease $[167,186,187]$ as well as of other pathologies.

\section{Conclusions}

The inflammatory response to tissue injury is characterized by recruitment and activation of immune cells with localized release of reactive oxygen species, serine proteases, and activation of the enzymes of the coagulation cascade. Such response although pivotal for the organism's defense may also lead to secondary effects not always beneficial to the homeostasis of the vascular bed and of the injured tissue. This might be particularly true when inflammation evolves from an acute response to a chronic condition. As a result, a number of biochemical modifications of the extracellular environment due to discharge of reactive oxygen species and activation of proteolytic enzymes in turn affects a number of molecular targets by either activating them or by suppressing their biological activity. Here we have focused on serine proteases involved in this process and their role in modifying proteins that are relevant to cardiovascular disease. The discovery over two decades ago that serine proteases such as thrombin can affect the vascular cell phenotype by activating specific cell membrane receptors, PARs, with a consequent cascade of intracellular signaling events shed a new light on our understanding of their mechanism of action. Nonetheless, serine proteases also target key players of the vascular homeostasis including growth factors implicated in angiogenesis and intimal hyperplasia such as FGFs, EGFs, PDGFs and VEGFs, and inflammatory mediators that impact vascular and tissue remodeling such as chemokines, CRP, and osteopontin. It is therefore reasonable to conclude that serine proteases affect the cardiovascular system by both PAR-dependent and -independent mechanisms. Thrombin cleavage of the HMW forms of FGF-2 is a paradigmatic example of post-translational control of a growth factor which may have profound repercussions on tissue and vascular remodeling secondary to injury. The elucidation of these mechanisms bears a potentially significant impact on the clinical approach targeting the activity of serine proteinases; for example, specific tools affecting certain biological effects of thrombin without altering its involvement in the coagulation cascade could be of paramount importance in the peri-operative care of cardiovascular interventions (Fig. 3). The lessons learnt by the use of wide spectrum serine protease inhibitors such as aprotinin in cardiovascular practice represent a sort of cautionary tale as a more refined targeting of serine proteases should be preferred over a generalized suppression of protease activity whose increased effectiveness on bleeding and/or inflammation might come with a series of dreadful and fateful side effects for the patient [188]. In this light, an increased knowledge of the mechanisms of action of the various serine proteases holds the key to finely targeted therapeutic tools.

Tissue remodeling secondary to injury represents a major mechanism that alters vascular homeostasis and proteases, particularly those associated with activated leukocytes and with the coagulation cascade, play a key role in this process. Understanding their biology and 


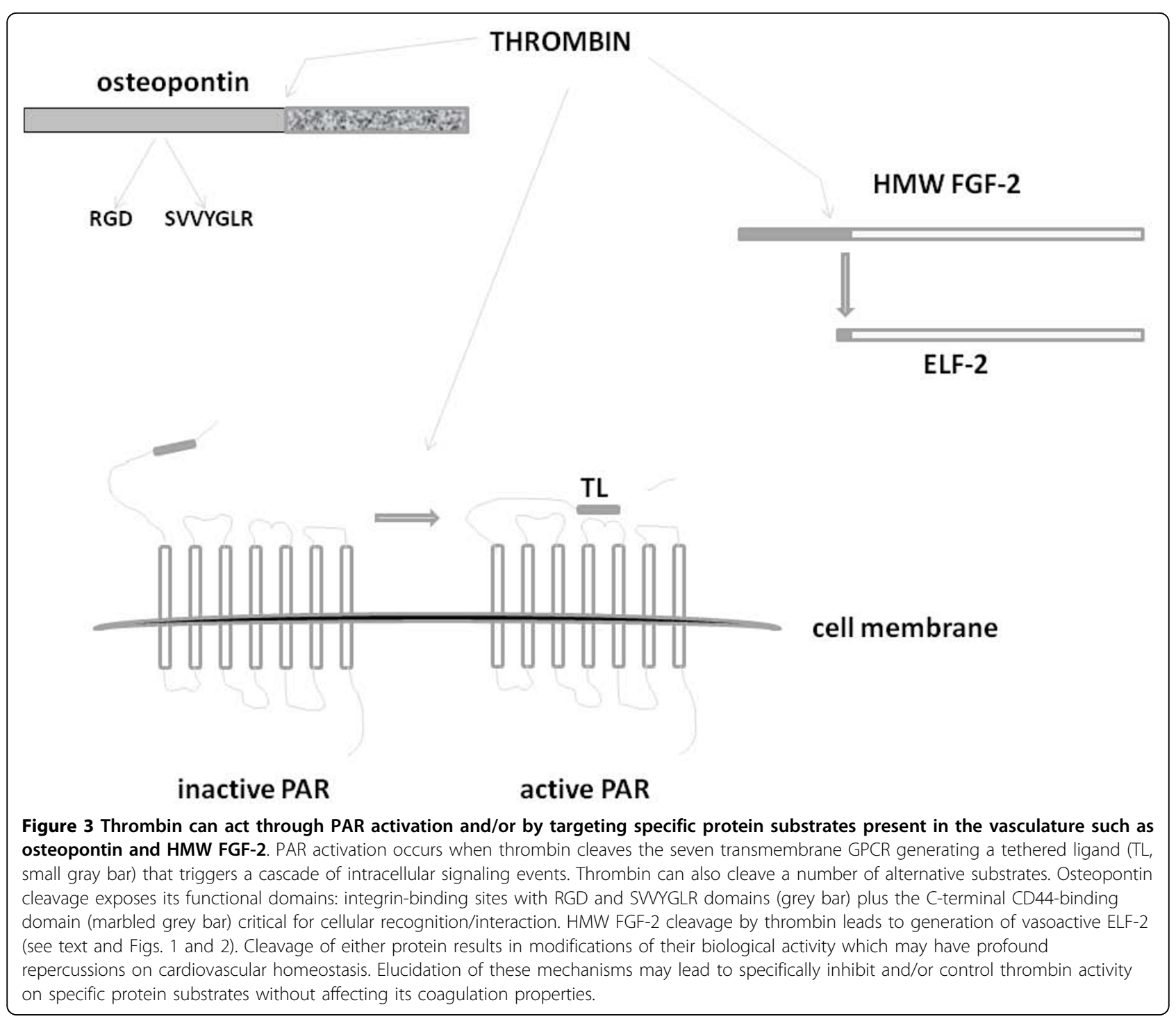

their effects on specific targets will afford a comprehensive approach to control their activity and a brighter outcome to prevent and/or cure the pathologies associated to their unwanted effects.

\section{Acknowledgements}

This work is dedicated to the loving memory of Dr. Stephen B. Colvin. This work was supported by The Sackler Faculty of Medicine Fund of Tel Aviv University in Israel (R.S.), NIH grants 5R01 HL070203, 5R01 CA136715, and R21 RAG033735 (P.M.), 5R21AG028785 (G.P.), and the Seymour Cohn Foundation for Cardiovascular Surgery Research.

\section{Author details}

'Department of Cardiothoracic Surgery, Rabin Medical Center and School of Medicine, Tel Aviv University, 39 Jabotinski St., Petah Tikva 49100, Israel.

${ }^{2}$ Department of Cardiothoracic Surgery, New York University School of Medicine, 530 First Avenue, New York, NY 10016, USA. ${ }^{3}$ Department of Cell Biology, New York University School of Medicine, 530 First Avenue, New York, NY 10016, USA.

\section{Authors' contributions}

RS contributed to the writing of this manuscript. PJY contributed to the writing of this manuscript. JP contributed to the writing of this manuscript. ACG contributed to the writing of this manuscript. PM contributed to the writing of this manuscript. GP contributed to the writing of this manuscript. All authors read and approved the final manuscript.

\section{Competing interests}

The authors declare that they have no competing interests.

Received: 19 March 2010 Accepted: 30 August 2010

Published: 30 August 2010

\section{References}

1. Libby P, Geng YJ, Aikawa M, Schoenbeck U, Mach F, Clinton SK, Sukhova GK, Lee RT: Macrophages and atherosclerotic plaque stability. Curr Opin Lipidol 1996, 7:330-335.

2. Suganami T, Nishida J, Ogawa Y: A paracrine loop between adipocytes and macrophages aggravates inflammatory changes: role of free fatty acids and tumor necrosis factor alpha. Arterioscler Thromb Vasc Biol 2005, 25:2062-2068.

3. Van Put DJ, Van Osselaer N, De Meyer GR, Andries LJ, Kockx MM, De Clerck LS, Bult H: Role of polymorphonuclear leukocytes in collar-induced 
intimal thickening in the rabbit carotid artery. Arterioscler Thromb Vasc Biol 1998, 18:915-921.

4. Granger DN, Vowinkel T, Petnehazy T: Modulation of the inflammatory response in cardiovascular disease. Hypertension 2004, 43:924-931.

5. Mugge A, Heistad DD, Padgett RC, Waack BJ, Densen P, Lopez JA: Mechanisms of contraction induced by human leukocytes in normal and atherosclerotic arteries. Circ Res 1991, 69:871-880.

6. Marcondes S, Antunes E: The plasma and tissue kininogen-kallikrein-kinin system: role in the cardiovascular system. Curr Med Chem Cardiovasc Hematol Agents 2005, 3:33-44.

7. Pejler G, Ronnberg E, Waern I, Wernersson S: Mast cell proteases: multifaceted regulators of inflammatory disease. Blood 2010, 115:4981-4990.

8. Malik AB, Lo SK, Bizios R: Thrombin-induced alterations in endothelial permeability. Ann N Y Acad Sci 1986, 485:293-309.

9. Sharony R, Pintucci G, Saunders PC, Grossi EA, Baumann FG, Galloway AC, Mignatti $P$ : Matrix metalloproteinase expression in vein grafts: role of inflammatory mediators and extracellular signal-regulated kinases- 1 and -2. Am J Physiol Heart Circ Physiol 2006, 290:H1651-1659.

10. Puente XS, Sanchez LM, Gutierrez-Fernandez A, Velasco G, Lopez-Otin C: A genomic view of the complexity of mammalian proteolytic systems. Biochem Soc Trans 2005, 33:331-334.

11. Puente XS, Lopez-Otin C: A genomic analysis of rat proteases and protease inhibitors. Genome Res 2004, 14:609-622.

12. Ramachandran R, Hollenberg MD: Proteinases and signalling: pathophysiological and therapeutic implications via PARs and more. $\mathrm{Br} J$ Pharmacol 2008, 153(Suppl 1):S263-282.

13. Weiss SJ: Tissue destruction by neutrophils. N Engl J Med 1989, 320:365-376

14. Leger AJ, Covic L, Kuliopulos A: Protease-activated receptors in cardiovascular diseases. Circulation 2006, 114:1070-1077.

15. Hollenberg MD, Compton SJ: International Union of Pharmacology. XXVIII. Proteinase-activated receptors. Pharmacol Rev 2002, 54:203-217.

16. Riewald M, Ruf W: Science review: role of coagulation protease cascades in sepsis. Crit Care 2003, 7:123-129.

17. Borensztajn K, Peppelenbosch MP, Spek CA: Factor Xa: at the crossroads between coagulation and signaling in physiology and disease. Trends Mol Med 2008, 14:429-440.

18. Jacques SL, LeMasurier M, Sheridan PJ, Seeley SK, Kuliopulos A: Substrateassisted catalysis of the PAR1 thrombin receptor. Enhancement of macromolecular association and cleavage. J Biol Chem 2000, 275:40671-40678.

19. Vu TK, Wheaton VI, Hung DT, Charo I, Coughlin SR: Domains specifying thrombin-receptor interaction. Nature 1991, 353:674-677.

20. Wettschureck N, Offermanns S: Mammalian G proteins and their cell type specific functions. Physiol Rev 2005, 85:1159-1204.

21. Steinhoff M, Buddenkotte J, Shpacovitch V, Rattenholl A, Moormann C, Vergnolle N, Luger TA, Hollenberg MD: Proteinase-activated receptors: transducers of proteinase-mediated signaling in inflammation and immune response. Endocr Rev 2005, 26:1-43.

22. Scarborough RM, Naughton MA, Teng W, Hung DT, Rose J, Vu TK, Wheaton VI, Turck CW, Coughlin SR: Tethered ligand agonist peptides. Structural requirements for thrombin receptor activation reveal mechanism of proteolytic unmasking of agonist function. J Biol Chem 1992, 267:13146-13149.

23. Minami T, Sugiyama A, Wu SQ, Abid R, Kodama T, Aird WC: Thrombin and phenotypic modulation of the endothelium. Arterioscler Thromb Vasc Biol 2004, 24:41-53.

24. Gerszten RE, Chen J, Ishii M, Ishii K, Wang L, Nanevicz T, Turck CW, Vu TK, Coughlin SR: Specificity of the thrombin receptor for agonist peptide is defined by its extracellular surface. Nature 1994, 368:648-651.

25. Covic L, Gresser AL, Talavera J, Swift S, Kuliopulos A: Activation and inhibition of $\mathrm{G}$ protein-coupled receptors by cell-penetrating membrane-tethered peptides. Proc Natl Acad Sci USA 2002, 99:643-648.

26. Offermanns $S$, Toombs CF, Hu YH, Simon Ml: Defective platelet activation in G alpha(q)-deficient mice. Nature 1997, 389:183-186.

27. Trumel $C$, Payrastre B, Plantavid M, Hechler B, Viala C, Presek $P$, Martinson EA, Cazenave JP, Chap H, Gachet C: A key role of adenosine diphosphate in the irreversible platelet aggregation induced by the PAR1-activating peptide through the late activation of phosphoinositide 3-kinase. Blood 1999, 94:4156-4165.
28. Garcia JG, Patterson C, Bahler C, Aschner J, Hart CM, English D: Thrombin receptor activating peptides induce $\mathrm{Ca} 2+$ mobilization, barrier dysfunction, prostaglandin synthesis, and platelet-derived growth factor mRNA expression in cultured endothelium. J Cell Physiol 1993, 156:541-549.

29. Garcia JG, Davis HW, Patterson CE: Regulation of endothelial cell gap formation and barrier dysfunction: role of myosin light chain phosphorylation. J Cell Physiol 1995, 163:510-522.

30. Vouret-Craviari V, Bourcier C, Boulter E, van Obberghen-Schilling E: Distinct signals via Rho GTPases and Src drive shape changes by thrombin and sphingosine-1-phosphate in endothelial cells. J Cell Sci 2002, 115:2475-2484.

31. Feistritzer C, Riewald M: Endothelial barrier protection by activated protein C through PAR1-dependent sphingosine 1-phosphate receptor-1 crossactivation. Blood 2005, 105:3178-3184.

32. Mosnier LO, Gale AJ, Yegneswaran S, Griffin JH: Activated protein C variants with normal cytoprotective but reduced anticoagulant activity. Blood 2004, 104:1740-1744.

33. Donati A, Romanelli M, Botticelli L, Valentini A, Gabbanelli V, Nataloni S, Principi T, Pelaia P, Bezemer R, Ince C: Recombinant activated protein C treatment improves tissue perfusion and oxygenation in septic patients measured by near-infrared spectroscopy. Crit Care 2009, 13(Suppl 5):S12.

34. Russo A, Soh UJ, Paing MM, Arora P, Trejo J: Caveolae are required for protease-selective signaling by protease-activated receptor-1. Proc Natl Acad Sci USA 2009, 106:6393-6397.

35. Nelken NA, Soifer SJ, O'Keefe J, Vu TK, Charo IF, Coughlin SR: Thrombin receptor expression in normal and atherosclerotic human arteries. I Clin Invest 1992, 90:1614-1621.

36. McNamara CA, Sarembock IJ, Gimple LW, Fenton JW, Coughlin SR, Owens GK: Thrombin stimulates proliferation of cultured rat aortic smooth muscle cells by a proteolytically activated receptor. J Clin Invest 1993, 91:94-98.

37. Takada M, Tanaka H, Yamada T, Ito O, Kogushi M, Yanagimachi M, Kawamura T, Musha T, Yoshida F, Ito M, et al: Antibody to thrombin receptor inhibits neointimal smooth muscle cell accumulation without causing inhibition of platelet aggregation or altering hemostatic parameters after angioplasty in rat. Circ Res 1998, 82:980-987.

38. Ahn JS, Choi S, Jang SH, Chang HJ, Kim JH, Nahm KB, Oh SW, Choi EY: Development of a point-of-care assay system for high-sensitivity Creactive protein in whole blood. Clin Chim Acta 2003, 332:51-59.

39. Ku DD, Zaleski JK: Receptor mechanism of thrombin-induced endothelium-dependent and endothelium-independent coronary vascular effects in dogs. J Cardiovasc Pharmacol 1993, 22:609-616.

40. Ku DD, Dai J: Expression of thrombin receptors in human atherosclerotic coronary arteries leads to an exaggerated vasoconstrictory response in vitro. J Cardiovasc Pharmacol 1997, 30:649-657.

41. Boire A, Covic L, Agarwal A, Jacques S, Sherifi S, Kuliopulos A: PAR1 is a matrix metalloprotease-1 receptor that promotes invasion and tumorigenesis of breast cancer cells. Cell 2005, 120:303-313.

42. Keuren JF, Wielders SJ, Ulrichts H, Hackeng T, Heemskerk JW, Deckmyn H, Bevers EM, Lindhout T: Synergistic effect of thrombin on collageninduced platelet procoagulant activity is mediated through proteaseactivated receptor-1. Arterioscler Thromb Vasc Biol 2005, 25:1499-1505.

43. Leger AJ, Jacques SL, Badar J, Kaneider NC, Derian CK, Andrade-Gordon P, Covic $L$, Kuliopulos A: Blocking the protease-activated receptor 1-4 heterodimer in platelet-mediated thrombosis. Circulation 2006, 113:1244-1254.

44. Hansen KK, Oikonomopoulou K, Li Y, Hollenberg MD: Proteinases, proteinase-activated receptors (PARs) and the pathophysiology of cancer and diseases of the cardiovascular, musculoskeletal, nervous and gastrointestinal systems. Naunyn Schmiedebergs Arch Pharmacol 2008, 377:377-392.

45. Hirano K, Kanaide $\mathrm{H}$ : Role of protease-activated receptors in the vascular system. J Atheroscler Thromb 2003, 10:211-225.

46. Carden D, Xiao F, Moak C, Willis BH, Robinson-Jackson S, Alexander S: Neutrophil elastase promotes lung microvascular injury and proteolysis of endothelial cadherins. Am J Physiol 1998, 275:H385-392.

47. Ginzberg HH, Cherapanov V, Dong Q, Cantin A, McCulloch CA, Shannon PT, Downey GP: Neutrophil-mediated epithelial injury during transmigration: role of elastase. Am J Physiol Gastrointest Liver Physiol 2001, 281:G705-717. 
48. Bedard M, McClure CD, Schiller NL, Francoeur C, Cantin A, Denis M: Release of interleukin-8, interleukin-6, and colony-stimulating factors by upper airway epithelial cells: implications for cystic fibrosis. Am J Respir Cell Mol Biol 1993, 9:455-462.

49. Nakamura H, Yoshimura K, McElvaney NG, Crystal RG: Neutrophil elastase in respiratory epithelial lining fluid of individuals with cystic fibrosis induces interleukin-8 gene expression in a human bronchial epithelial cell line. J Clin Invest 1992, 89:1478-1484.

50. Ariel A, Yavin EJ, Hershkoviz R, Avron A, Franitza S, Hardan I, Cahalon L, Fridkin M, Lider O: IL-2 induces T cell adherence to extracellular matrix: inhibition of adherence and migration by IL-2 peptides generated by leukocyte elastase. J Immunol 1998, 161:2465-2472.

51. Morrison HM, Kramps JA, Burnett D, Stockley RA: Lung lavage fluid from patients with alpha 1-proteinase inhibitor deficiency or chronic obstructive bronchitis: anti-elastase function and cell profile. Clin Sci (Lond) 1987, 72:373-381.

52. Ortiz-Munoz G, Houard X, Martin-Ventura JL, Ishida BY, Loyau S, Rossignol P, Moreno JA, Kane JP, Chalkley RJ, Burlingame AL, et al: HDL antielastase activity prevents smooth muscle cell anoikis, a potential new antiatherogenic property. FASEB J 2009, 23:3129-3139.

53. Ardissino D, Merlini PA, Ariens R, Coppola R, Bramucci E, Mannucci PM: Tissue-factor antigen and activity in human coronary atherosclerotic plaques. Lancet 1997, 349:769-771.

54. Taubman MB, Fallon JT, Schecter AD, Giesen P, Mendlowitz M, Fyfe BS, Marmur JD, Nemerson Y: Tissue factor in the pathogenesis of atherosclerosis. Thromb Haemost 1997, 78:200-204.

55. Abboud RT, Fera T, Johal S, Richter A, Gibson N: Effect of smoking on plasma neutrophil elastase levels. J Lab Clin Med 1986, 108:294-300.

56. Collier A, Jackson M, Bell D, Patrick AW, Matthews DM, Young RJ, Clarke BF, Dawes J: Neutrophil activation detected by increased neutrophil elastase activity in type 1 (insulin-dependent) diabetes mellitus. Diabetes Res 1989, 10:135-138.

57. Dollery CM, Owen CA, Sukhova GK, Krettek A, Shapiro SD, Libby P: Neutrophil elastase in human atherosclerotic plaques: production by macrophages. Circulation 2003, 107:2829-2836.

58. Owen CA, Campbell EJ: The cell biology of leukocyte-mediated proteolysis. J Leukoc Biol 1999, 65:137-150.

59. Boudier C, Godeau G, Hornebeck W, Robert L, Bieth JG: The elastolytic activity of cathepsin G: an ex vivo study with dermal elastin. Am J Respir Cell Mol Biol 1991, 4:497-503.

60. McDonnell J, Lobner JM, Knight WB, Lark MW, Green B, Poe M, Moore VL: Comparison of the proteoglycanolytic activities of human leukocyte elastase and human cathepsin $\mathrm{G}$ in vitro and in vivo. Connect Tissue Res 1993, 30:1-9.

61. Shamamian P, Schwartz JD, Pocock BJ, Monea S, Whiting D, Marcus SG, Mignatti P: Activation of progelatinase A (MMP-2) by neutrophil elastase, cathepsin G, and proteinase-3: a role for inflammatory cells in tumor invasion and angiogenesis. J Cell Physiol 2001, 189:197-206.

62. Shimoda N, Fukazawa N, Nonomura K, Fairchild RL: Cathepsin g is required for sustained inflammation and tissue injury after reperfusion of ischemic kidneys. Am J Pathol 2007, 170:930-940.

63. Sabri A, Alcott SG, Elouardighi H, Pak E, Derian C, Andrade-Gordon P, Kinnally K, Steinberg SF: Neutrophil cathepsin G promotes detachmentinduced cardiomyocyte apoptosis via a protease-activated receptorindependent mechanism. J Biol Chem 2003, 278:23944-23954.

64. Rafiq K, Hanscom M, Valerie K, Steinberg SF, Sabri A: Novel mode for neutrophil protease cathepsin G-mediated signaling: membrane shedding of epidermal growth factor is required for cardiomyocyte anoikis. Circ Res 2008, 102:32-41.

65. Shimizu K, Minami M, Shubiki R, Lopez-llasaca M, MacFarlane L, Asami Y, Li Y, Mitchell RN, Libby P: CC chemokine receptor-1 activates intimal smooth muscle-like cells in graft arterial disease. Circulation 2009, 120:1800-1813.

66. Vogiatzi K, Voudris V, Apostolakis S, Kochiadakis GE, Thomopoulou S, Zaravinos A, Spandidos DA: Genetic diversity of RANTES gene promoter and susceptibility to coronary artery disease and restenosis after percutaneous coronary intervention. Thromb Res 2009, 124:84-89.

67. Lim JK, Lu W, Hartley O, DeVico AL: N-terminal proteolytic processing by cathepsin G converts RANTES/CCL5 and related analogs into a truncated 4-68 variant. J Leukoc Biol 2006, 80:1395-1404.
68. Lim JK, Burns JM, Lu W, DeVico AL: Multiple pathways of amino terminal processing produce two truncated variants of RANTES/CCL5. J LeukoC Biol 2005, 78:442-452.

69. Omura $T$, Yoshiyama $M$, Kim S, Matsumoto $R$, Nakamura $Y$, Izumi $Y$, Ichijo $H$, Sudo T, Akioka $\mathrm{K}$, Iwao $\mathrm{H}$, et al: Involvement of apoptosis signalregulating kinase-1 on angiotensin II-induced monocyte chemoattractant protein-1 expression. Arterioscler Thromb Vasc Biol 2004, 24:270-275.

70. Helske S, Syvaranta S, Kupari M, Lappalainen J, Laine M, Lommi J, Turto H, Mayranpaa M, Werkkala K, Kovanen PT, Lindstedt KA: Possible role for mast cell-derived cathepsin $\mathrm{G}$ in the adverse remodelling of stenotic aortic valves. Eur Heart J 2006, 27:1495-1504.

71. Legedz L, Randon J, Sessa C, Baguet JP, Feugier P, Cerutti C, McGregor J, Bricca G: Cathepsin $G$ is associated with atheroma formation in human carotid artery. J Hypertens 2004, 22:157-166.

72. Entman ML, Michael L, Rossen RD, Dreyer WJ, Anderson DC, Taylor AA, Smith CW: Inflammation in the course of early myocardial ischemia. FASEB J 1991, 5:2529-2537.

73. Romson JL, Hook BG, Kunkel SL, Abrams GD, Schork MA, Lucchesi BR: Reduction of the extent of ischemic myocardial injury by neutrophil depletion in the dog. Circulation 1983, 67:1016-1023.

74. Bergese SD, Huang EH, Pelletier RP, Widmer MB, Ferguson RM, Orosz CG: Regulation of endothelial VCAM-1 expression in murine cardiac grafts. Expression of allograft endothelial VCAM-1 can be manipulated with antagonist of IFN-alpha or IL-4 and is not required for allograft rejection. Am J Pathol 1995, 147:166-175.

75. Takada M, Nadeau KC, Shaw GD, Marquette KA, Tilney NL: The cytokineadhesion molecule cascade in ischemia/reperfusion injury of the rat kidney. Inhibition by a soluble P-selectin ligand. J Clin Invest 1997, 99:2682-2690.

76. Klausner JM, Paterson IS, Goldman G, Kobzik L, Rodzen C, Lawrence R, Valeri CR, Shepro D, Hechtman HB: Postischemic renal injury is mediated by neutrophils and leukotrienes. Am J Physiol 1989, 256:F794-802.

77. Miura M, Fu X, Zhang QW, Remick DG, Fairchild RL: Neutralization of Gro alpha and macrophage inflammatory protein- 2 attenuates renal ischemia/reperfusion injury. Am J Pathol 2001, 159:2137-2145.

78. Robache-Gallea S, Morand V, Bruneau JM, Schoot B, Tagat E, Realo E, Chouaib S, Roman-Roman S: In vitro processing of human tumor necrosis factor-alpha. J Biol Chem 1995, 270:23688-23692.

79. Kim KU, Kwon OJ, Jue DM: Pro-tumour necrosis factor cleavage enzyme in macrophage membrane/particulate. Immunology 1993, 80:134-139.

80. Scuderi P: Suppression of human leukocyte tumor necrosis factor secretion by the serine protease inhibitor $p$-toluenesulfonyl-L-arginine methyl ester (TAME). J Immunol 1989, 143:168-173.

81. Mezyk-Kopec R, Bzowska M, Mickowska B, Mak P, Potempa J, Bereta J: Effects of elastase and cathepsin $G$ on the levels of membrane and soluble TNFalpha. Biol Chem 2005, 386:801-811.

82. van Kessel KP, van Strijp JA, Verhoef J: Inactivation of recombinant human tumor necrosis factor-alpha by proteolytic enzymes released from stimulated human neutrophils. J Immunol 1991, 147:3862-3868.

83. Joosten LA, van De Loo FA, Lubberts E, Helsen MM, Netea MG, van Der Meer JW, Dinarello CA, van Den Berg WB: An IFN-gamma-independent proinflammatory role of IL-18 in murine streptococcal cell wall arthritis. J Immunol 2000, 165:6553-6558.

84. Takeda K, Tsutsui H, Yoshimoto T, Adachi O, Yoshida N, Kishimoto T, Okamura H, Nakanishi K, Akira S: Defective NK cell activity and Th1 response in IL-18-deficient mice. Immunity 1998, 8:383-390.

85. Tsutsui H, Kayagaki N, Kuida K, Nakano H, Hayashi N, Takeda K, Matsui K, Kashiwamura S, Hada T, Akira S, et al: Caspase-1-independent, Fas/Fas ligand-mediated IL-18 secretion from macrophages causes acute liver injury in mice. Immunity 1999, 11:359-367.

86. Bank U, Reinhold D, Schneemilch C, Kunz D, Synowitz HJ, Ansorge S: Selective proteolytic cleavage of IL-2 receptor and IL-6 receptor ligand binding chains by neutrophil-derived serine proteases at foci of inflammation. J Interferon Cytokine Res 1999, 19:1277-1287.

87. Porteu F, Brockhaus M, Wallach D, Engelmann H, Nathan CF: Human neutrophil elastase releases a ligand-binding fragment from the $75-\mathrm{kDa}$ tumor necrosis factor (TNF) receptor. Comparison with the proteolytic activity responsible for shedding of TNF receptors from stimulated neutrophils. J Biol Chem 1991, 266:18846-18853. 
88. Pintucci G, lacoviello L, Castelli MP, Amore C, Evangelista V, Cerletti C, Donati MB: Cathepsin G-induced release of PAI-1 in the culture medium of endothelial cells: a new thrombogenic role for polymorphonuclear leukocytes? J Lab Clin Med 1993, 122:69-79.

89. Yang JJ, Kettritz R, Falk RJ, Jennette JC, Gaido ML: Apoptosis of endothelial cells induced by the neutrophil serine proteases proteinase 3 and elastase. Am J Pathol 1996, 149:1617-1626.

90. Preston GA, Zarella CS, Pendergraft WF, Rudolph EH, Yang JJ, Sekura SB, Jennette JC, Falk RJ: Novel effects of neutrophil-derived proteinase 3 and elastase on the vascular endothelium involve in vivo cleavage of NFkappaB and proapoptotic changes in JNK, ERK, and p38 MAPK signaling pathways. J Am Soc Nephrol 2002, 13:2840-2849.

91. Uchida Y, Freitas MC, Zhao D, Busuttil RW, Kupiec-Weglinski JW: The inhibition of neutrophil elastase ameliorates mouse liver damage due to ischemia and reperfusion. Liver Transp/ 2009, 15:939-947.

92. Kakuta Y, Aoshiba K, Nagai A: C-reactive protein products generated by neutrophil elastase promote neutrophil apoptosis. Arch Med Res 2006, 37:456-460.

93. Ginzberg HH, Shannon PT, Suzuki T, Hong O, Vachon E, Moraes T, Abreu MT, Cherepanov V, Wang X, Chow CW, Downey GP: Leukocyte elastase induces epithelial apoptosis: role of mitochondial permeability changes and Akt. Am J Physiol Gastrointest Liver Physiol 2004, 287:G286-298.

94. Schlessinger J: Cell signaling by receptor tyrosine kinases. Cell 2000, 103:211-225.

95. Melo LG, Pachori AS, Gnecchi M, Dzau VJ: Genetic therapies for cardiovascular diseases. Trends Mol Med 2005, 11:240-250.

96. Mitra AK, Gangahar DM, Agrawal DK: Cellular, molecular and immunological mechanisms in the pathophysiology of vein graft intimal hyperplasia. Immunol Cell Biol 2006, 84:115-124.

97. Newby AC, Zaltsman AB: Molecular mechanisms in intimal hyperplasia. J Pathol 2000, 190:300-309.

98. Tsopanoglou NE, Maragoudakis ME: Role of thrombin in angiogenesis and tumor progression. Semin Thromb Hemost 2004, 30:63-69.

99. Kalmes A, Vesti BR, Daum G, Abraham JA, Clowes AW: Heparin blockade of thrombin-induced smooth muscle cell migration involves inhibition of epidermal growth factor (EGF) receptor transactivation by heparinbinding EGF-like growth factor. Circ Res 2000, 87:92-98.

100. Sastre AP, Grossmann S, Reusch HP, Schaefer M: Requirement of an intermediate gene expression for biphasic ERK1/2 activation in thrombin-stimulated vascular smooth muscle cells. J Biol Chem 2008, 283:25871-25878.

101. Alvarez RH, Kantarjian HM, Cortes JE: Biology of platelet-derived growth factor and its involvement in disease. Mayo Clin Proc 2006, 81:1241-1257.

102. Millette E, Rauch BH, Defawe O, Kenagy RD, Daum G, Clowes AW: Plateletderived growth factor-BB-induced human smooth muscle cell proliferation depends on basic FGF release and FGFR-1 activation. Circ Res 2005, 96:172-179.

103. Benezra M, Vlodavsky I, Ishai-Michaeli R, Neufeld G, Bar-Shavit R: Thrombininduced release of active basic fibroblast growth factor-heparan sulfate complexes from subendothelial extracellular matrix. Blood 1993, 81:3324-3331.

104. Chao TK, Rifai A, Ka SM, Yang SM, Shui HA, Lin YF, Sytwu HK, Lee WH, Kung JT, Chen A: The endogenous immune response modulates the course of IgA-immune complex mediated nephropathy. Kidney Int 2006, 70:283-297.

105. Cucina A, Borrelli V, Lucarelli M, Sterpetti AV, Cavallaro A, Strom R, SantoroD'Angelo L, Scarpa S: Autocrine production of basic fibroblast growth factor translated from novel synthesized mRNA mediates thrombininduced mitogenesis in smooth muscle cells. Cell Biochem Funct 2002, 20:39-46.

106. Rauch BH, Millette E, Kenagy RD, Daum G, Clowes AW: Thrombin- and factor Xa-induced DNA synthesis is mediated by transactivation of fibroblast growth factor receptor-1 in human vascular smooth muscle cells. Circ Res 2004, 94:340-345.

107. Rauch BH, Scholz GA, Baumgartel-Allekotte D, Censarek P, Fischer JW, Weber AA, Schror $\mathrm{K}$ : Cholesterol enhances thrombin-induced release of fibroblast growth factor-2 in human vascular smooth muscle cells. Arterioscler Thromb Vasc Biol 2007, 27:e20-25.

108. Stouffer GA, Runge MS: The role of secondary growth factor production in thrombin-induced proliferation of vascular smooth muscle cells. Semin Thromb Hemost 1998, 24:145-150.
109. Weiss $\mathrm{RH}$, Maduri M: The mitogenic effect of thrombin in vascular smooth muscle cells is largely due to basic fibroblast growth factor. $J$ Biol Chem 1993, 268:5724-5727.

110. Pintucci G, Moscatelli D, Saponara F, Biernacki PR, Baumann FG, Bizekis C, Galloway AC, Basilico C, Mignatti P: Lack of ERK activation and cell migration in FGF-2-deficient endothelial cells. FASEB J 2002, 16:598-600.

111. Pintucci G, Steinberg BM, Seghezzi G, Yun J, Apazidis A, Baumann FG, Grossi EA, Colvin SB, Mignatti P, Galloway AC: Mechanical endothelial damage results in basic fibroblast growth factor-mediated activation of extracellular signal-regulated kinases. Surgery 1999, 126:422-427.

112. Itoh N, Ornitz DM: Evolution of the Fgf and Fgfr gene families. Trends Genet 2004, 20:563-569.

113. Florkiewicz RZ, Sommer A: Human basic fibroblast growth factor gene encodes four polypeptides: three initiate translation from non-AUG codons. Proc Natl Acad Sci USA 1989, 86:3978-3981.

114. Vagner S, Gensac MC, Maret A, Bayard F, Amalric F, Prats H, Prats AC: Alternative translation of human fibroblast growth factor 2 mRNA occurs by internal entry of ribosomes. Mol Cell Biol 1995, 15:35-44.

115. Sorensen V, Nilsen T, Wiedlocha A: Functional diversity of FGF-2 isoforms by intracellular sorting. Bioessays 2006, 28:504-514

116. Yu PJ, Ferrari G, Galloway AC, Mignatti P, Pintucci G: Basic fibroblast growth factor (FGF-2): the high molecular weight forms come of age. $J$ Cell Biochem 2007, 100:1100-1108.

117. Krejci P, Prochazkova J, Bryja V, Kozubik A, Wilcox WR: Molecular pathology of the fibroblast growth factor family. Hum Mutat 2009, 30:1245-1255.

118. Mann KG, Brummel K, Butenas S: What is all that thrombin for? J Thromb Haemost 2003, 1:1504-1514.

119. Rickles FR, Patierno S, Fernandez PM: Tissue factor, thrombin, and cancer. Chest 2003, 124:58S-68S.

120. Even-Ram S, Uziely B, Cohen P, Grisaru-Granovsky S, Maoz M, Ginzburg Y, Reich R, Vlodavsky I, Bar-Shavit R: Thrombin receptor overexpression in malignant and physiological invasion processes. Nat Med 1998, 4:909-914.

121. Tsopanoglou NE, Maragoudakis ME: On the mechanism of thrombininduced angiogenesis. Potentiation of vascular endothelial growth factor activity on endothelial cells by up-regulation of its receptors. J Biol Chem 1999, 274:23969-23976.

122. Daniel TO, Gibbs VC, Milfay DF, Garovoy MR, Williams LT: Thrombin stimulates c-sis gene expression in microvascular endothelial cells. J Biol Chem 1986, 261:9579-9582.

123. Papadimitriou E, Manolopoulos VG, Hayman GT, Maragoudakis ME, Unsworth BR, Fenton JW, Lelkes PI: Thrombin modulates vectorial secretion of extracellular matrix proteins in cultured endothelial cells. Am J Physiol 1997, 272:C1112-1122.

124. Coughlin SR: Protease-activated receptors in hemostasis, thrombosis and vascular biology. J Thromb Haemost 2005, 3:1800-1814.

125. Cao H, Dronadula N, Rao GN: Thrombin induces expression of FGF-2 via activation of PI3K-Akt-Fra-1 signaling axis leading to DNA synthesis and motility in vascular smooth muscle cells. Am J Physiol Cell Physiol 2006, 290:C172-182.

126. Yu PJ, Ferrari G, Pirelli L, Galloway AC, Mignatti P, Pintucci G: Thrombin cleaves the high molecular weight forms of basic fibroblast growth factor (FGF-2): a novel mechanism for the control of FGF-2 and thrombin activity. Oncogene 2008, 27:2594-2601.

127. Borgono CA, Diamandis EP: The emerging roles of human tissue kallikreins in cancer. Nat Rev Cancer 2004, 4:876-890.

128. Borgono CA, Michael IP, Diamandis EP: Human tissue kallikreins: physiologic roles and applications in cancer. Mol Cancer Res 2004, 2:257-280.

129. Sotiropoulou G, Pampalakis G, Diamandis EP: Functional roles of human kallikrein-related peptidases. J Biol Chem 2009, 284:32989-32994.

130. Borgono CA, Grass L, Soosaipillai A, Yousef GM, Petraki CD, Howarth DH, Fracchioli S, Katsaros D, Diamandis EP: Human kallikrein 14: a new potential biomarker for ovarian and breast cancer. Cancer Res 2003, 63:9032-9041.

131. Kim H, Scorilas A, Katsaros D, Yousef GM, Massobrio M, Fracchioli S, Piccinno R, Gordini G, Diamandis EP: Human kallikrein gene 5 (KLK5) expression is an indicator of poor prognosis in ovarian cancer. $\mathrm{Br} J$ Cancer 2001, 84:643-650.

132. Blaber SI, Ciric B, Christophi GP, Bernett MJ, Blaber M, Rodriguez M, Scarisbrick IA: Targeting kallikrein 6 proteolysis attenuates CNS inflammatory disease. FASEB J 2004, 18:920-922. 
133. Scarisbrick IA, Blaber SI, Lucchinetti CF, Genain CP, Blaber M, Rodriguez M: Activity of a newly identified serine protease in CNS demyelination. Brain 2002, 125:1283-1296.

134. Oikonomopoulou K, Diamandis EP, Hollenberg MD: Kallikrein-related peptidases: proteolysis and signaling in cancer, the new frontier. Biol Chem 2010, 391:299-310.

135. Oikonomopoulou K, Hansen KK, Saifeddine M, Tea I, Blaber M, Blaber SI, Scarisbrick I, Andrade-Gordon P, Cottrell GS, Bunnett NW, et al: Proteinaseactivated receptors, targets for kallikrein signaling. J Bio/ Chem 2006, 281:32095-32112.

136. al-Ani B, Saifeddine M, Hollenberg MD: Detection of functional receptors for the proteinase-activated-receptor-2-activating polypeptide, SLIGRL$\mathrm{NH} 2$, in rat vascular and gastric smooth muscle. Can J Physiol Pharmacol 1995, 73:1203-1207.

137. Hollenberg MD, Saifeddine M, Sandhu S, Houle S, Vergnolle N: Proteinaseactivated receptor-4: evaluation of tethered ligand-derived peptides as probes for receptor function and as inflammatory agonists in vivo. $\mathrm{Br} J$ Pharmacol 2004, 143:443-454

138. Vergnolle N, Derian CK, D'Andrea MR, Steinhoff M, Andrade-Gordon P: Characterization of thrombin-induced leukocyte rolling and adherence: a potential proinflammatory role for proteinase-activated receptor-4. $J$ Immunol 2002, 169:1467-1473.

139. Vergnolle N, Wallace JL, Bunnett NW, Hollenberg MD: Protease-activated receptors in inflammation, neuronal signaling and pain. Trends Pharmacol Sci 2001, 22:146-152

140. Meloni FJ, Gustafson EJ, Schmaier AH: High molecular weight kininogen binds to platelets by its heavy and light chains and when bound has altered susceptibility to kallikrein cleavage. Blood 1992, 79:1233-1244.

141. Ichinose A, Fujikawa K, Suyama T: The activation of pro-urokinase by plasma kallikrein and its inactivation by thrombin. J Biol Chem 1986, 261:3486-3489.

142. Pejler $G$, Abrink M, Ringvall M, Wernersson S: Mast cell proteases. Adv Immunol 2007, 95:167-255.

143. Berger $P$, Perng DW, Thabrew $H_{1}$, Compton SJ, Cairns JA, McEuen AR, Marthan R, Tunon De Lara JM, Walls AF: Tryptase and agonists of PAR-2 induce the proliferation of human airway smooth muscle cells. J Appl Physiol 2001, 91:1372-1379.

144. Stack MS, Johnson DA: Human mast cell tryptase activates single-chain urinary-type plasminogen activator (pro-urokinase). J Biol Chem 1994, 269:9416-9419.

145. Taipale J, Lohi J, Saarinen J, Kovanen PT, Keski-Oja J: Human mast cell chymase and leukocyte elastase release latent transforming growth factor-beta 1 from the extracellular matrix of cultured human epithelial and endothelial cells. J Biol Chem 1995, 270:4689-4696.

146. Dell'Italia $L J$, Husain A: Dissecting the role of chymase in angiotensin II formation and heart and blood vessel diseases. Curr Opin Cardiol 2002, 17:374-379.

147. Schwartz LB, Bradford TR, Littman BH, Wintroub BU: The fibrinogenolytic activity of purified tryptase from human lung mast cells. J Immunol 1985, 135:2762-2767.

148. Cuatrecasas P: Properties of the insulin receptor of isolated fat cell membranes. J Biol Chem 1971, 246:7265-7274.

149. Kono T, Barham FW: Insulin-like effects of trypsin on fat cells. Localization of the metabolic steps and the cellular site affected by the enzyme. $J$ Biol Chem 1971, 246:6204-6209.

150. Shoelson SE, White MF, Kahn CR: Tryptic activation of the insulin receptor. Proteolytic truncation of the alpha-subunit releases the beta-subunit from inhibitory control. J Biol Chem 1988, 263:4852-4860.

151. Lafleur MA, Hollenberg MD, Atkinson SJ, Knauper V, Murphy G, Edwards DR: Activation of pro-(matrix metalloproteinase-2) (pro-MMP-2) by thrombin is membrane-type-MMP-dependent in human umbilical vein endothelial cells and generates a distinct 63 kDa active species. Biochem J 2001, 357:107-115.

152. Ridker PM, Hennekens $\mathrm{CH}$, Buring JE, Rifai N: C-reactive protein and other markers of inflammation in the prediction of cardiovascular disease in women. N Engl J Med 2000, 342:836-843.

153. Shephard EG, Anderson R, Beer SM, Van Rensburg CE, de Beer FC: Neutrophil lysosomal degradation of human CRP: CRP-derived peptides modulate neutrophil function. Clin Exp Immunol 1988, 73:139-145.

154. Zhong W, Zen Q, Tebo J, Schlottmann K, Coggeshall M, Mortensen RF: Effect of human C-reactive protein on chemokine and chemotactic factor-induced neutrophil chemotaxis and signaling. J Immunol 1998, 161:2533-2540.

155. Ballou SP, Lozanski G: Induction of inflammatory cytokine release from cultured human monocytes by C-reactive protein. Cytokine 1992, 4:361-368

156. Pasceri V, Cheng JS, Willerson JT, Yeh ET: Modulation of C-reactive protein-mediated monocyte chemoattractant protein-1 induction in human endothelial cells by anti-atherosclerosis drugs. Circulation 2001, 103:2531-2534.

157. Cermak J, Key NS, Bach RR, Balla J, Jacob HS, Vercellotti GM: C-reactive protein induces human peripheral blood monocytes to synthesize tissue factor. Blood 1993, 82:513-520.

158. Nakagomi A, Freedman SB, Geczy CL: Interferon-gamma and lipopolysaccharide potentiate monocyte tissue factor induction by $\mathrm{C}$ reactive protein: relationship with age, sex, and hormone replacement treatment. Circulation 2000, 101:1785-1791.

159. Verma S, Li SH, Badiwala MV, Weisel RD, Fedak PW, Li RK, Dhillon B, Mickle DA: Endothelin antagonism and interleukin- 6 inhibition attenuate the proatherogenic effects of C-reactive protein. Circulation 2002, 105:1890-1896

160. Gulkarov I, Pintucci G, Bohmann K, Saunders PC, Sullivan RF, Ferrari G, Mignatti $P$, Galloway AC: Mechanisms of c-reactive protein up-regulation in arterialized vein grafts. Surgery 2006, 139:254-262.

161. Venugopal SK, Devaraj S, Yuhanna I, Shaul P, Jialal I: Demonstration that Creactive protein decreases eNOS expression and bioactivity in human aortic endothelial cells. Circulation 2002, 106:1439-1441.

162. Venugopal SK, Devaraj S, Jialal I: C-reactive protein decreases prostacyclin release from human aortic endothelial cells. Circulation 2003, 108:1676-1678.

163. Devaraj S, Xu DY, Jialal I: C-reactive protein increases plasminogen activator inhibitor-1 expression and activity in human aortic endothelial cells: implications for the metabolic syndrome and atherothrombosis. Circulation 2003, 107:398-404.

164. Danenberg HD, Szalai AJ, Swaminathan RV, Peng L, Chen Z, Seifert P, Fay WP, Simon DI, Edelman ER: Increased thrombosis after arterial injury in human C-reactive protein-transgenic mice. Circulation 2003, 108:512-515

165. Liaw L, Lombardi DM, Almeida MM, Schwartz SM, deBlois D, Giachelli CM: Neutralizing antibodies directed against osteopontin inhibit rat carotid neointimal thickening after endothelial denudation. Arterioscler Thromb Vasc Biol 1997, 17:188-193.

166. Scatena M, Liaw L, Giachelli CM: Osteopontin: a multifunctional molecule regulating chronic inflammation and vascular disease. Arterioscler Thromb Vasc Biol 2007, 27:2302-2309.

167. O'Brien ER, Garvin MR, Stewart DK, Hinohara T, Simpson JB, Schwartz SM, Giachelli CM: Osteopontin is synthesized by macrophage, smooth muscle, and endothelial cells in primary and restenotic human coronary atherosclerotic plaques. Arterioscler Thromb 1994, 14:1648-1656.

168. Ohmori R, Momiyama Y, Taniguchi H, Takahashi R, Kusuhara M, Nakamura H, Ohsuzu F: Plasma osteopontin levels are associated with the presence and extent of coronary artery disease. Atherosclerosis 2003 170:333-337.

169. Kato R, Momiyama Y, Ohmori R, Tanaka N, Taniguchi H, Arakawa K, Kusuhara M, Nakamura H, Ohsuzu F: High plasma levels of osteopontin in patients with restenosis after percutaneous coronary intervention. Arterioscler Thromb Vasc Biol 2006, 26:e1-2.

170. Golledge J, Muller J, Shephard N, Clancy P, Smallwood L, Moran C, Dear AE, Palmer LJ, Norman PE: Association between osteopontin and human abdominal aortic aneurysm. Arterioscler Thromb Vasc Biol 2007, 27:655-660.

171. Christensen B, Schack L, Klaning E, Sorensen ES: Osteopontin is cleaved at multiple sites close to its integrin-binding motifs in milk and is a novel substrate for plasmin and cathepsin D. J Biol Chem 2010, 285:7929-7937.

172. Agnihotri R, Crawford HC, Haro H, Matrisian LM, Havrda MC, Liaw L: Osteopontin, a novel substrate for matrix metalloproteinase-3 (stromelysin-1) and matrix metalloproteinase-7 (matrilysin). J Biol Chem 2001, 276:28261-28267.

173. Yokosaki Y, Matsuura N, Sasaki T, Murakami I, Schneider H, Higashiyama S, Saitoh Y, Yamakido M, Taooka Y, Sheppard D: The integrin alpha(9)beta(1) binds to a novel recognition sequence (SWVGLR) in the thrombincleaved amino-terminal fragment of osteopontin. J Biol Chem 1999 274:36328-36334. 
174. Smith LL, Cheung HK, Ling LE, Chen J, Sheppard D, Pytela R, Giachelli CM: Osteopontin $\mathrm{N}$-terminal domain contains a cryptic adhesive sequence recognized by alpha9beta1 integrin. J Biol Chem 1996, 271:28485-28491.

175. Zheng W, Li R, Pan H, He D, Xu R, Guo TB, Guo Y, Zhang JZ: Role of osteopontin in induction of monocyte chemoattractant protein 1 and macrophage inflammatory protein 1beta through the NF-kappaB and MAPK pathways in rheumatoid arthritis. Arthritis Rheum 2009, 60:1957-1965.

176. Hamada Y, Yuki K, Okazaki M, Fujitani W, Matsumoto T, Hashida MK, Harutsugu K, Nokihara K, Daito M, Matsuura N, Takahashi J: Osteopontinderived peptide SVVYGLR induces angiogenesis in vivo. Dent Mater J 2004, 23:650-655.

177. Giachelli CM, Lombardi D, Johnson RJ, Murry CE, Almeida M: Evidence for a role of osteopontin in macrophage infiltration in response to pathological stimuli in vivo. Am J Pathol 1998, 152:353-358.

178. Lai CF, Seshadri V, Huang K, Shao JS, Cai J, Vattikuti R, Schumacher A, Loewy AP, Denhardt DT, Rittling SR, Towler DA: An osteopontin-NADPH oxidase signaling cascade promotes pro-matrix metalloproteinase 9 activation in aortic mesenchymal cells. Circ Res 2006, 98:1479-1489.

179. Yamamoto N, Sakai F, Kon S, Morimoto J, Kimura C, Yamazaki H, Okazaki I, Seki N, Fujii T, Uede T: Essential role of the cryptic epitope SLAYGLR within osteopontin in a murine model of rheumatoid arthritis. J Clin Invest 2003, 112:181-188.

180. Giachelli CM, Pichler R, Lombardi D, Denhardt DT, Alpers CE, Schwartz SM, Johnson RJ: Osteopontin expression in angiotensin II-induced tubulointerstitial nephritis. Kidney Int 1994, 45:515-524.

181. Parrish AR, Ramos KS: Osteopontin mRNA expression in a chemicallyinduced model of atherogenesis. Ann N Y Acad Sci 1995, 760:354-356.

182. Matsui Y, Rittling SR, Okamoto H, Inobe M, Jia N, Shimizu T, Akino M, Sugawara T, Morimoto J, Kimura C, et al: Osteopontin deficiency attenuates atherosclerosis in female apolipoprotein E-deficient mice. Arterioscler Thromb Vasc Biol 2003, 23:1029-1034

183. Speer MY, McKee MD, Guldberg RE, Liaw L, Yang HY, Tung E, Karsenty G, Giachelli CM: Inactivation of the osteopontin gene enhances vascular calcification of matrix Gla protein-deficient mice: evidence for osteopontin as an inducible inhibitor of vascular calcification in vivo. J Exp Med 2002, 196:1047-1055.

184. Atalar E, Ozturk E, Ozer N, Haznedaroglu IC, Kepez A, Coskun S, Aksoyek S, Ovunc K, Kes S, Kirazli S, Ozmen F: Plasma soluble osteopontin concentrations are increased in patients with rheumatic mitral stenosis and associated with the severity of mitral valve calcium. Am J Cardiol 2006, 98:817-820.

185. Yu PJ, Skolnick A, Ferrari G, Heretis K, Mignatti P, Pintucci G, Rosenzweig B, Diaz-Cartelle J, Kronzon I, Perk G, et al: Correlation between plasma osteopontin levels and aortic valve calcification: potential insights into the pathogenesis of aortic valve calcification and stenosis. J Thorac Cardiovasc Surg 2009, 138:196-199.

186. Kwon HM, Hong BK, Kang TS, Kwon K, Kim HK, Jang Y, Choi D, Park HY, Kang SM, Cho SY, Kim HS: Expression of osteopontin in calcified coronary atherosclerotic plaques. J Korean Med Sci 2000, 15:485-493.

187. Momiyama Y, Ohmori R, Fayad ZA, Kihara T, Tanaka N, Kato R, Taniguchi H, Nagata M, Nakamura H, Ohsuzu F: Associations between plasma osteopontin levels and the severities of coronary and aortic atherosclerosis. Atherosclerosis 2010, 210:668-670.

188. Lien M, Milbrandt EB: A disheartening story: aprotinin in cardiac surgery. Crit Care 2006, 10:317.

doi:10.1186/1476-9255-7-45

Cite this article as: Sharony et al:: Protein targets of inflammatory serine proteases and cardiovascular disease. Journal of Inflammation 2010 7:45.

\section{Submit your next manuscript to BioMed Central and take full advantage of:}

- Convenient online submission

- Thorough peer review

- No space constraints or color figure charges

- Immediate publication on acceptance

- Inclusion in PubMed, CAS, Scopus and Google Scholar

- Research which is freely available for redistribution

Submit your manuscript at www.biomedcentral.com/submit 